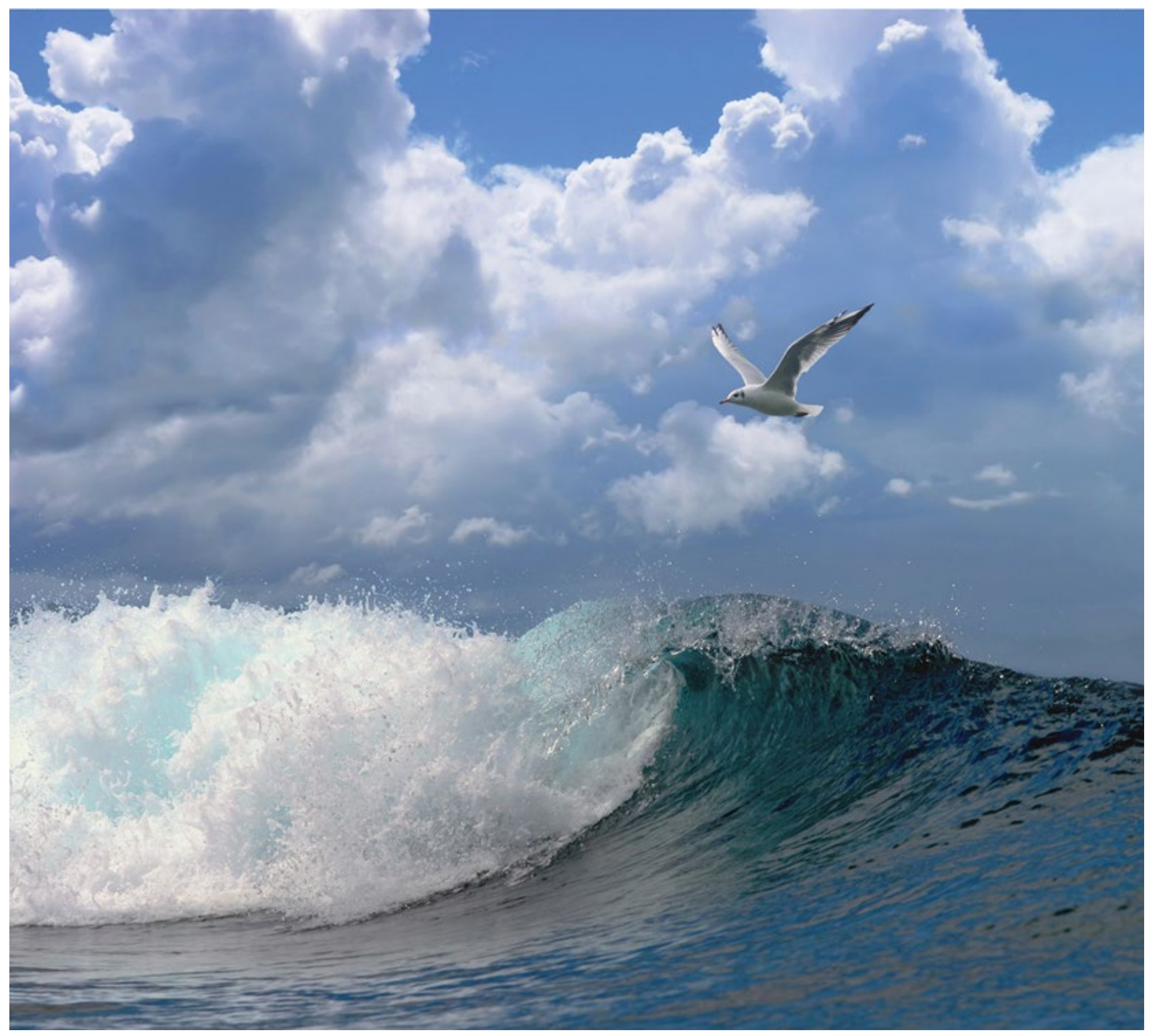

The use of video-techniques for monitoring and quantification of mobile fauna in marine cultivation systems 


\section{The use of video-techniques for monitoring and quantification of mobile fauna in marine cultivation systems}

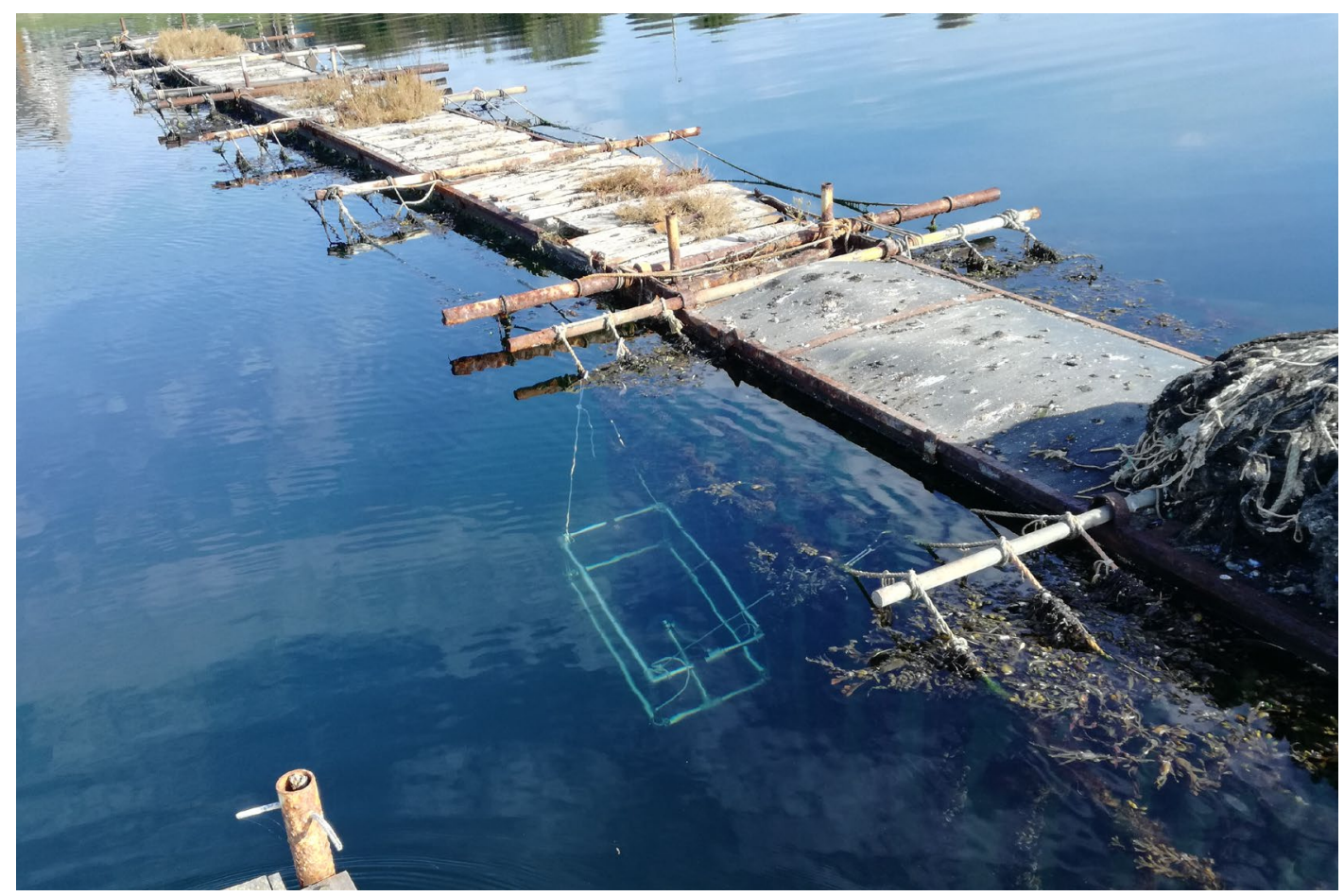

Author(s): $\quad$ L. Tonk, M.S. Bernard, H.M. Jansen

Publication date: Februay 2019 


\section{(C) Wageningen Marine Research}

Wageningen Marine Research, an institute within the legal entity Stichting Wageningen Research (a foundation under Dutch private law) represented by Dr. M.C.Th. Scholten, Managing Director

KvK nr. 09098104,

WMR BTW nr. NL 8113.83.696.B16.

Code BIC/SWIFT address: RABONL2U

IBAN code: NL 73 RABO 0373599285
Wageningen Marine Research accepts no liability for consequential damage, nor for damage resulting from applications of the results of work or other data obtained from Wageningen Marine Research. Client indemnifies Wageningen Marine Research from claims of third parties in connection with this application.

All rights reserved. No part of this publication may be reproduced and / or published, photocopied or used in any other way without the written permission of the publisher or author. 
Keywords: video-techniques, biodiversity, seaweed farming, shellfish aquaculture.

This report can be downloaded for free from https://doi.org/10.18174/471068

Wageningen Marine Research provides no printed copies of reports

Wageningen Marine Research is ISO 9001:2008 certified.

Photo cover: Miriam Bernard 



\section{Contents}

$\begin{array}{lr}\text { Summary } & 6\end{array}$

$\begin{array}{lll}1 & \text { Introduction } & 7\end{array}$

$\begin{array}{lll}1.1 & \text { General introduction } & 7\end{array}$

$\begin{array}{ll}1.2 & \text { Aim \& objectives of the study }\end{array}$

2 Literature review camera techniques $\quad 9$

2.1 Methodology $\quad 9$

2.2 Literature Review $\quad 9$

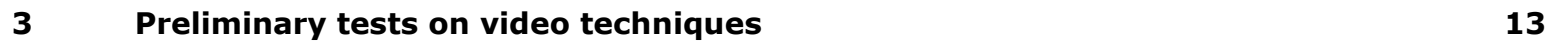

$\begin{array}{lll}3.1 & \text { Methodology } & 13\end{array}$

$\begin{array}{lll}3.1 .1 & \text { Study sites } & 13\end{array}$

$\begin{array}{lll}3.1 .2 & \text { Camera systems } & 14\end{array}$

$\begin{array}{lll}3.1 .3 & \text { Video analysis } & 15\end{array}$

3.2 Results 15

3.2.1 Mobile fauna in the Eastern Scheldt and North Sea $\quad 15$

$\begin{array}{lll}3.2 .2 & \text { Baited camera and transects } & 17\end{array}$

4 Workshop "Use of advanced tools and video techniques for monitoring and quantification in aquatic environments"

$5 \quad$ Conclusions and recommendations $\quad 22$

5.1 Methods for studying marine mobile fauna $\quad 22$

5.2 Environmental factors affecting the use of cameras $\quad 22$

5.3 Recommendations for the optimization of BRUV systems, deployment and experimental design 


\section{Summary}

Innovative tools and techniques are needed to support the development of new marine production chains and multi-use solutions at sea. In the framework of the sustainable development of marine production chains, such as seaweed and mussel cultivation, it is important to develop tools that describe and quantify ecosystem impacts and services of these cultivation systems. Development and upscaling of (marine) production systems may have a significant effect on biodiversity, an important indicator for ecosystem functioning. The exact processes between marine biomass production and biodiversity are largely undescribed, especially for new cultivation systems and cultivation areas. The aim of this study was to assess the use of video techniques to determine biodiversity (qualitative and if possible quantitatively), with a focus on the attraction of mobile fauna (fish). Traditionally biodiversity is quantified by field sampling with grabs (benthic fauna), traps or nets (mobile fauna) followed by identification in the laboratory. The recent introduction of high performance, affordable cameras is changing how video techniques can be used to study marine biodiversity. In this report we investigated different video techniques and their advantages and constrains in terms of applicability to quantify mobile fauna. This is done by means of (i) a literature research, (ii) preliminary testing of video techniques and (iii) an expert-workshop within WMR to improve our understanding of the various video techniques already in use in aquatic research, current advancements and limitations.

The literature study highlighted that while significant advance has been made in regard to technical applications and improvement of experimental set-ups, extracting biologically or ecologically important information from photographs or videos still remains a challenge. This was also one of the main outcomes of the workshop. For future research, innovative solutions for data processing are essential to ensure the continuing practical use of camera systems. Preliminary tests with a baited remote underwater video (BRUV) system and video transects showed potential for the current baited camera design. However, this system needs to be compared with other methods (transects) in order to identify potential biases. Adjusting the BRUV system design to the specific characteristics of seaweed or mussel farms (smaller fish in low visibility systems) is one of the recommendations made.

Further development of innovative techniques to determine changes in biodiversity in and around aquaculture farms will contribute to monitoring programs to support careful management of marine resources. 


\section{Introduction}

\subsection{General introduction}

Oceans offer a considerable and largely undiscovered source of resources such as biomass (food, protein, high-end products), energy, water and nature. The ambition is to utilize these resources in the next decades for a sustainable bio-based society in which land and ocean are integrally connected. To achieve this, careful management of marine resources with a nature inclusive approach is essential. The transition towards sustainable energy will cause an exponential increase in the number of offshore wind parks leading to various multi-use opportunities including possibilities for the reinforcement of nature values in these areas. Oceans are now more frequently considered for the production of food with high nutritive content as well as for other application to support a growing world population (Blue Revolution). A nature-inclusive approach is desirable when realizing these new developments in which nature-based solutions, careful management of resources, a multi-functional approach and circular economy (a regenerative design in which resource input and waste, energy leakage and emission are minimized) are key (Poelman, 2019).

In the framework of the sustainable development of marine production chains, such as seaweed and mussel cultivation, it is important to describe and quantify ecosystem impacts and services of these systems. This will provide better perspectives for development in a broad social context, specifically for the business case seaweed, which is relatively new in the Netherlands compared to mussel cultivation. In addition, it will contribute to innovative concepts for multi-use of space at sea. Examples of potential ecosystem services provided by seaweed production include an increased biodiversity or the improvement of water quality (Wood et al. 2017). However, negative effects or impacts are also conceivable, such as the attraction of invasive species or the risk of surpassing the carrying capacity of an ecosystem by extracting too many nutrients (McKindsey et al. 2006, Wood et al. 2017). The effects of these interactions depend on the scale of production, the produced species, the cultivation location and the ecosystem itself. The challenge and necessity is to quantify these interactions. However, quantitative data of ecosystem services and impacts are very limited and mainly restricted to other aquaculture sectors than seaweed farming, such as fish farming and nearand in-shore shellfish cultivation (Dealteris et al. 2004, Callier et al. 2018).

Innovative tools and techniques to quantify ecosystem interactions are therefore needed. Recently, there has been significant progress in underwater imagery techniques, including aerial and multispectral imagery as well as light detection and sonar techniques. The aim of this study was to assess the use of imagery techniques to quantify biodiversity as an ecosystem service provided by seaweed farms. Biodiversity is an important measure for ecosystem health and functioning. Here we will focus on the attraction of mobile fauna (fish) and its quantification. Aerial imagery techniques were deemed unsuitable for this purpose since growing seaweed biomass is likely to block visibility from above the farm. Therefore, we focussed on underwater video systems in this study.

\subsection{Aim \& objectives of the study}

In this study we investigated different video techniques and their applicability to quantify mobile diversity associated to seaweed and mussel farms. We did this firstly by means of a literature review on video techniques used to study marine mobile fauna. Secondly, preliminary tests on video techniques were performed to test the application and limitation of surveying fish in the Eastern Scheldt. A baited remote underwater video (BRUV) system was chosen for this purpose because it can be operated without the assistance of a diver and it is the recommended technique for areas where fish are scarce (Whitmarsh et al. 2017). In addition, transects with a GoPro on a pole were conducted to determine the frequency of observation of fish species in comparison to the BRUV system. 
Finally, a workshop was conducted to improve our understanding of video technique related activities within WMR, current advancements and limitations 


\section{Literature review camera techniques}

\section{$2.1 \quad$ Methodology}

The literature search was conducted using the Google Scholar database and relevant keywords, including "underwater video", "remote underwater video", "baited camera" and "BRUV". Additionally, the references of all retrieved studies were checked in order to identify relevant literature. The review was restricted to studies focussing on marine mobile fauna.

\subsection{Literature Review}

Various techniques are available to investigate marine biodiversity of mobile fauna. For a long time, studies have been based mainly on extractive methods, such as fishing or dredging. However, due to technical progress in video cameras, sensors, battery life and information storage, novel techniques have become accessible and affordable for most users during the last decades (reviewed by Murphy and Jenkins 2010). Camera imagery has thus become a powerful tool for studying marine biodiversity on different scales, from individuals to entire ecosystems.

Video techniques may either be operated by divers or remotely. As diver operated video systems (DOV) require the operation of a person underwater, they are limited in the number of observations carried out and in the depth range. The presence of a diver in the water may furthermore disturb the mobile fauna, thereby potentially biasing the results (Mallet and Pelletier 2014).

These restrictions can be overcome by the use of remote video techniques. Remote underwater video systems (RUV) are either stationary or mobile, with the latter being either autonomous or towed (TOWV), i.e. moving along a transect of predefined size at low speed (0.1-1 $\mathrm{ms}^{-1}$, Mallet and Pelletier 2014). RUV systems can be applied at a wide depth range as well as under low light conditions with additional lights attached or infrared light (Mallet and Pelletier 2014). Since the first use of underwater video systems in the Aquarium of the Zoological Society of London in 1949 (Barnes 1952), this technique has been used increasingly in marine ecology studies (Fedra and Machan 1979, Dunbrack and Zielinski 2003, Stokesbury et al. 2004, Pelletier et al. 2012). Two or more cameras can be used simultaneously (stereo video techniques) in order to obtain three dimensional images that facilitate size estimation and can also help to identify individuals, thereby minimizing the risk of double counting individuals (Pelletier et al. 2012, Mallet and Pelletier 2014). Remote underwater cameras may also be coupled to rotating systems which enables a $360^{\circ}$ view (Mallet et al. 2014).

When using RUV systems, it is important to choose the orientation of the system in relation to the sea bottom (horizontal or vertical) carefully, as it may affect both the abundance and composition of observed species (Wraith 2007, Langlois et al. 2010). While vertical observation may be necessary for some fish species that can only be identified by their dorsal fins (Cappo et al. 2007), horizontal observations often allows a broader view on observed animals. Another important factor is the deployment height of the camera in the water column. Cameras may be applied from just above seabed or suspended in the water column just below sea surface which can equally affect the observation of certain fish species (Mallet and Pelletier 2014).

Baited remote underwater video (BRUV) systems consist of one or more cameras that film the surrounding area of a bait which is used to attract fish. BRUV systems are particularly appropriate for sampling generalist carnivores, large predators and mobile species and may also be particularly useful in areas where fish are scarce (Whitmarsh et al. 2017). As the bait composition affects the species observations, the choice of bait is crucial for the experimental outcome (Munro 1974, Wraith 2007) According to Cappo et al. (2007), the observations made by BRUV systems are biased, as mainly 
carnivores are attracted by the bait (Cappo et al. 2007). Other authors showed that indeed the number of predators was higher than observed by non-baited cameras, but the observed numbers of herbivorous or omnivorous fish were not decreased (Harvey et al. 2007). Similarly, De Vos et al. (2014) reported that also herbivores and omnivores were detected by a BRUV system.

The experimental conditions for BRUV systems reported in previous studies show very high variation, especially with regard to the optimal deployment time, i.e. the so-called soaking time. While Watson et al. (2005) observed effective bait attraction after 25-40 minutes, they recommend at least 60 minutes for future studies. Other authors recommend a deployment time of 120 minutes (SantanaGarcon et al. 2014). However, since the distance and range of the attraction by the bait cannot be tested easily, the use of BRUV systems requires pilot studies for each particular experimental sites to determine the necessary number of replicates and the optimal soak time (Gladstone et al. 2012). In order to generalize the use of BRUV systems and enable a better reproducibility and comparability, Whitmarsh et al. (2017) proposed a list of basic 24 variables that should be reported for every study (Table 1).

Table 1. Variables as a protocol for factors to include in the method section of studies on video techniques.

Adapted from Whitmarsh et al. 2017

\begin{tabular}{|c|c|c|}
\hline Context & Variable & Example \\
\hline When and where & $\begin{array}{l}\text { Year published } \\
\text { Study location } \\
\text { Geographical area } \\
\text { Aquatic realm } \\
\text { Habitat type }\end{array}$ & $\begin{array}{l}\text { 1996, 2006, } 2016 \\
\text { Adelaide, South Australia, Australia } \\
\text { Temperate, tropical, polar } \\
\text { Marine, estuarine, freshwater } \\
\text { Seagrass, rocky reef }\end{array}$ \\
\hline About the video & $\begin{array}{l}\text { Name of systems } \\
\text { Orientation of camera(s) } \\
\text { Number and type of cameras } \\
\text { Type of length measurement } \\
\text { Maximal visible range } \\
\text { Soak time } \\
\text { Distance between replicates }\end{array}$ & $\begin{array}{l}\text { BRUVS } \\
\text { Horizontal, vertical (to substrate) } \\
1 \text { or } 2 \text {, GoPro Hero } 3+\text {, Panasonic HandyCam } \\
\text { Fork length using stereo-BRUVS } \\
3 \mathrm{~m} \text {, to bait bag } \\
30,60 \mathrm{~min} \\
250,500 \mathrm{~m}\end{array}$ \\
\hline About the bait & $\begin{array}{l}\text { Ytype } \\
\text { Quantity } \\
\text { Preparation method } \\
\text { Deployment method }\end{array}$ & $\begin{array}{l}\text { Sardines, Sardinops sagax } \\
500,1000 \mathrm{~g} \\
\text { Crushed, whole, chopped } \\
\text { Mesh bag, perforated PVC bait container }\end{array}$ \\
\hline About the deployment & $\begin{array}{l}\text { Minumum depth } \\
\text { Maximum depth } \\
\text { Variation in depth (range) }\end{array}$ & $\begin{array}{l}3,10 \mathrm{~m} \\
50,25 \mathrm{~m} \\
47,15 \mathrm{~m}\end{array}$ \\
\hline About the sampling design and analysis & $\begin{array}{l}\text { Number of replicates } \\
\text { Video metric used } \\
\text { Software used } \\
\text { Taxa included } \\
\% \text { identified to species level }\end{array}$ & $\begin{array}{l}3,6 \\
\text { MaxN etc. } \\
\text { EventMeasure, VLC etc. } \\
\text { Teleost, Chondrichthyes, Cephalopoda, Crustacea } \\
75 \%\end{array}$ \\
\hline
\end{tabular}


Besides video systems, also single images can be used to study marine biodiversity. Camera traps that are activated by moving animals are very well established in terrestrial ecosystems (Silver et al. 2004, O'Connell et al. 2011) they are not yet widely used in the marine environment. However, recently Williams et al. (2014) developed a promising triggered camera system for the use in marine systems. The resulting stereo image analysis allowed an estimation of fish size, position and orientation.

Some of the above named techniques have been compared in studies and it was shown that there is no single technique that outperforms the others. Rather, some techniques are more appropriate for specific purposes. For instance, a greater species richness was observed using stereo BRUV systems than DOV, whereas DOV reported a larger abundance of small-bodied fish (Watson et al. 2005). Similarly, Colton and Swearer (2010) detected more mobile predators and more taxonomically distinct populations using a remotely-operated BRUV system than using a video system operated by a diver. Pita et al. (2014), on the other hand, found that more precise and complete inventories were obtained by divers than by RUV systems. Generally, authors seem to agree that for comprehensive and reliable studies, a combination of several methods may be necessary (Watson et al. 2005, Mallet et al. 2014) and that the implication of the different sampling techniques has to be considered when analysing the data (Watson et al. 2010).

When comparing different studies on video techniques, authors seem to disagree on the best method to present the data (Stobart et al. 2015). MaxN is a traditionally used and very conservative value which reports the maximal number of fish observed in a single video frame. Tot $N$, on the other hand, reports the total number of individuals per recording. Mean $N$ is a recently suggested alternative which reports the average of the mean $\operatorname{MaxN}$ from 5 minute periods throughout the duration of a recording. Additionally, the first time of arrival of an individual $\left(t_{1}\right)$ is a value that seems to be correlated to the total species abundance and may therefore also be worth reporting (Stobart et al. 2015). For a comparison of the main advantages and shortcomings of each observation technique see Table 2.

While significant advance has been made with regard to technical applications and improvement of experimental set-ups, extracting biologically or ecologically important information from photographs or videos still lags behind. The conversion of imagery data into quantitative data remains a slow process and in most cases automated and streamlined techniques are lacking. Furthermore, battery life is still a limiting factor in many studies. For future research, innovative solutions for data processing are needed to ensure the continuing practical use of camera systems.

Table 2. Comparison of main advantages and shortcomings of each observation technique and future recommendations

Adapted from Mallet \& Pelletier 2014

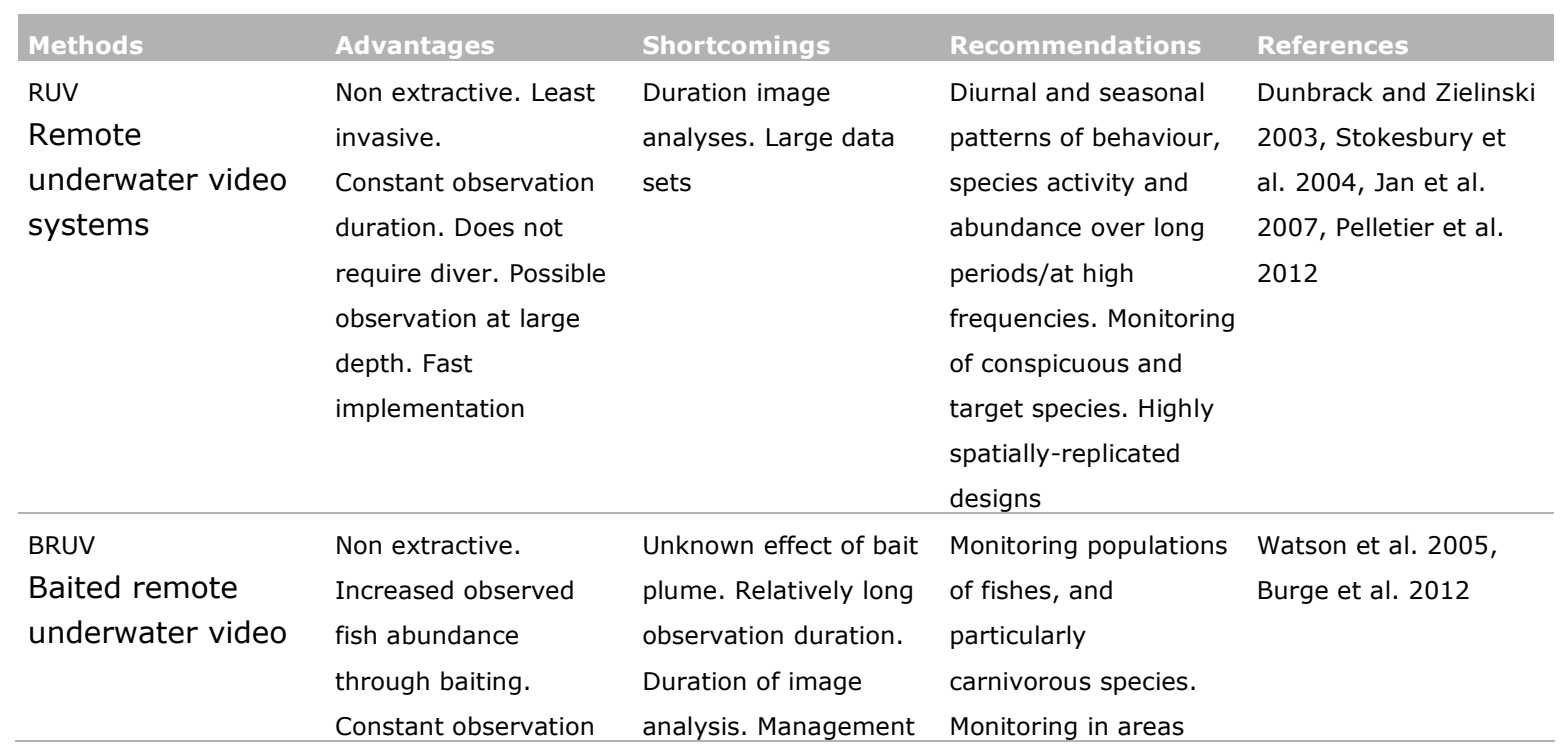




\begin{tabular}{|c|c|c|c|c|}
\hline & $\begin{array}{l}\text { duration. Does not } \\
\text { require diver. } \\
\text { Opportunity to work in } \\
\text { deep water }\end{array}$ & of large data sets & $\begin{array}{l}\text { where diversity and } \\
\text { abundance are low }\end{array}$ & \\
\hline $\begin{array}{l}\text { DOV } \\
\text { diver operated } \\
\text { video systems }\end{array}$ & $\begin{array}{l}\text { Non extractive. Does } \\
\text { not require scientific } \\
\text { diver }\end{array}$ & $\begin{array}{l}\text { All effects associated } \\
\text { with the presence of a } \\
\text { diver underwater (see } \\
\text { below). Duration of } \\
\text { image analysis }\end{array}$ & $\begin{array}{l}\text { Study benthic cover } \\
\text { and macrofauna }\end{array}$ & $\begin{array}{l}\text { Langlois et al. 2010, } \\
\text { Pelletier } 2011\end{array}$ \\
\hline $\begin{array}{l}\text { Towv } \\
\text { Towed underwater } \\
\text { video systems }\end{array}$ & $\begin{array}{l}\text { Non extractive. Does } \\
\text { not require diver. } \\
\text { Opportunity to work in } \\
\text { deep water. Fast } \\
\text { implementation. Large } \\
\text { spatial coverage. }\end{array}$ & $\begin{array}{l}\text { May disturb the } \\
\text { ecosystem due to } \\
\text { vessel noise. } \\
\text { Management of large } \\
\text { data sets. Duration of } \\
\text { image analysis }\end{array}$ & $\begin{array}{l}\text { Monitoring habitat and } \\
\text { fixed benthic species } \\
\text { over large areas }\end{array}$ & $\begin{array}{l}\text { Spencer et al. 2005, } \\
\text { Grabowski et al. } 2012\end{array}$ \\
\hline Camera traps & $\begin{array}{l}\text { Non extractive. Least } \\
\text { invasive. Does not } \\
\text { require diver. Possible } \\
\text { observation at large } \\
\text { depth. Fast } \\
\text { implementation }\end{array}$ & $\begin{array}{l}\text { Duration of image } \\
\text { analysis. Sensitive to } \\
\text { moving particles }\end{array}$ & $\begin{array}{l}\text { Monitoring in areas } \\
\text { where diversity and } \\
\text { abundance are low. } \\
\text { Estimation of fish size, } \\
\text { position and } \\
\text { orientation }\end{array}$ & Williams et al. 2014 \\
\hline
\end{tabular}




\section{Preliminary tests on video techniques}

\subsection{Methodology}

Baited cameras were deployed at three different sites: 1 . in a seaweed farm, 2 . in a mussel farm and 3. in a small yacht harbour. In addition, transects with a GoPro on a pole were conducted at site 1 to determine the frequency of observation of fish species as a comparison to the BRUV system.

Four aspects have been investigated to assess the potential use and technical set-up of BRUV systems 1a) Testing and optimization of a BRUV (baited remote underwater video) system to survey fish diversity

1b) Preliminary test of video transects to determine fish diversity

1c) Testing the use of time-lapse versus continuous recording camera setting

1d) Assessing the influence of different types of bait on the observed fish assemblage

\subsubsection{Study sites}

Three study sites were used to test the baited camera set-up (Fig. 1A). Sites were chosen based on visibility and potential encounters with fish. To ensure easy deployment and optimal visibility we only placed the baited-camera set-up or performed transects when wind speed was less than 10 knots (4 Beaufort) this was done on recommendations of Seaweed Harvest Holland personnel.

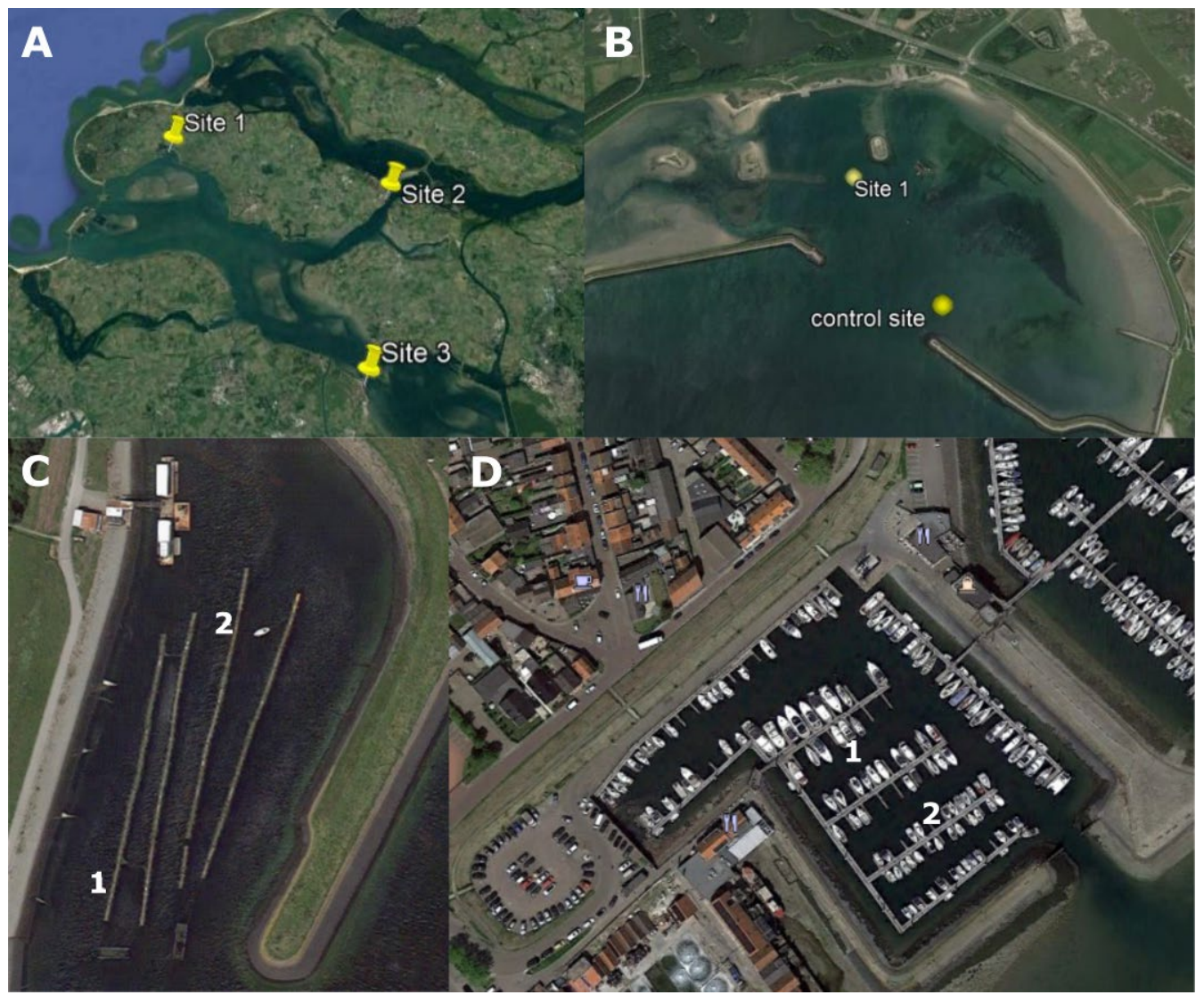

Figure 1. A. Experimental sites in the Eastern Scheldt. B. Schelphoek, experimental site 1. C. Mussel farm 't Zijpe, experimental site 2. D. Yacht harbour, Yerseke, experimental site 3.

The first location was the seaweed farm ( \pm 0.5 ha) of Seaweed Harvest Holland $\left(51^{\circ} 41.6^{\prime} \mathrm{N}, 3^{\circ} 48.5^{\prime} \mathrm{E}\right.$, Fig. 1B), situated in Schelphoek bay on the northern side of the Eastern Scheldt on Schouwen- 
Duiveland. During the summer season, the green seaweed Ulva is grown on vertical lines suspended from a top line just under the water surface (Fig. 2A and B). Visibility was estimated about $1.5 \mathrm{~m}$ but decreased to approximately $0.5 \mathrm{~m}$ throughout the duration of the deployment due to the upcoming tide. The second study site was located at the mussel cultivation site (Erik Veerhoek) 't Zijpe $\left(51^{\circ} 39.0^{\prime} \mathrm{N}, 4^{\circ} 5.8^{\prime} \mathrm{E}\right.$, Fig. $\left.1 \mathrm{C}\right)$, near Bruinisse. The mussel farm ( $\pm 0.5 \mathrm{ha}$ ) is located in a sheltered pocket of the Eastern Scheldt and is therefore hardly affected by tides. Furthermore, visibility is high due to filtration by the mussels. The third test site was at the Yerseke yacht harbour $\left(51^{\circ} 29.8^{\prime} \mathrm{N}\right.$, $\left.4^{\circ} 3.2^{\prime} E\right)$.

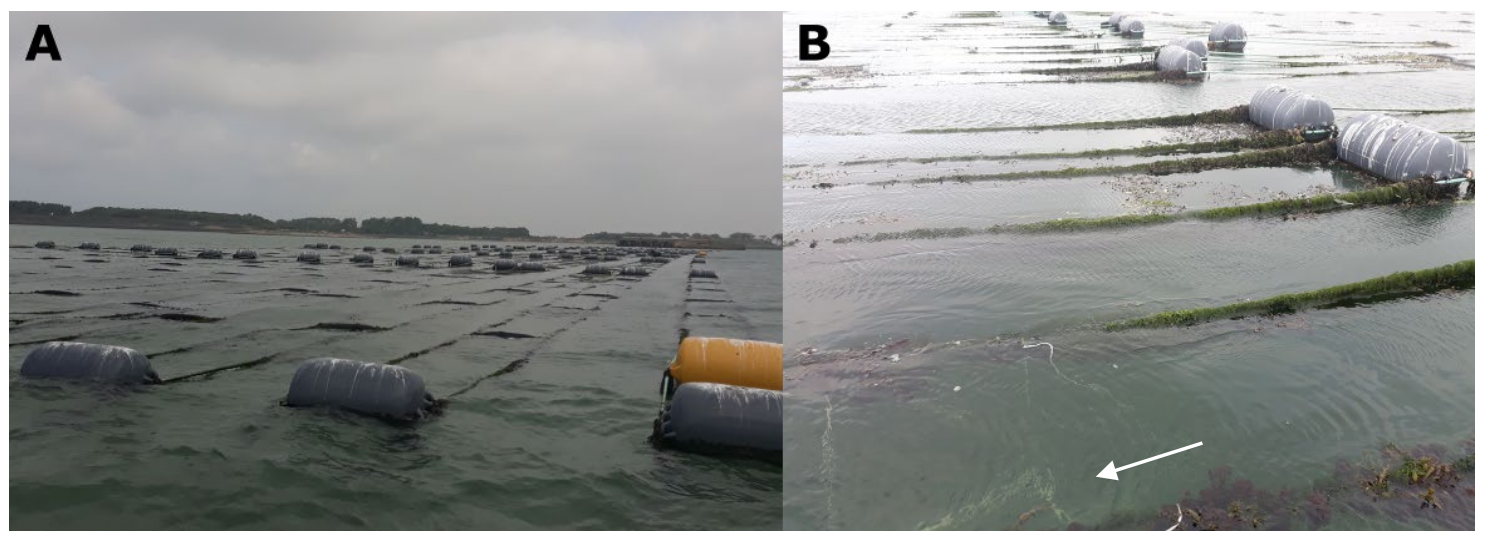

Figure 2. Seaweed farm Seaweed Harvest Holland at Schelphoek. A. Ulva cultivation ropes. B. Deployment of the BRUV system (indicated with arrow).

\subsubsection{Camera systems}

Video recording was conducted with GoPro Hero 5 session cameras with stored on 32GB memory cards, i.e. maximal recording time of 2 hours, and a recording rate of 30 frames per second at a resolution of $1080 \mathrm{p}$. Field of view was set to wide and video stabilisation was activated. Storage and battery life were the limiting factors in terms of length of video.

The BRUV rig consisted of a stainless steel frame $(40 \times 47 \times 80 \mathrm{~cm}), 2$ GoPro cameras and an arm $(35 \mathrm{~cm})$ to which a bait bag was attached by means of tie-wraps (Fig. 3A). The BRUV system was attached to horizontal cultivation lines by means of ropes and 4 karabiners (Fig. 3B).

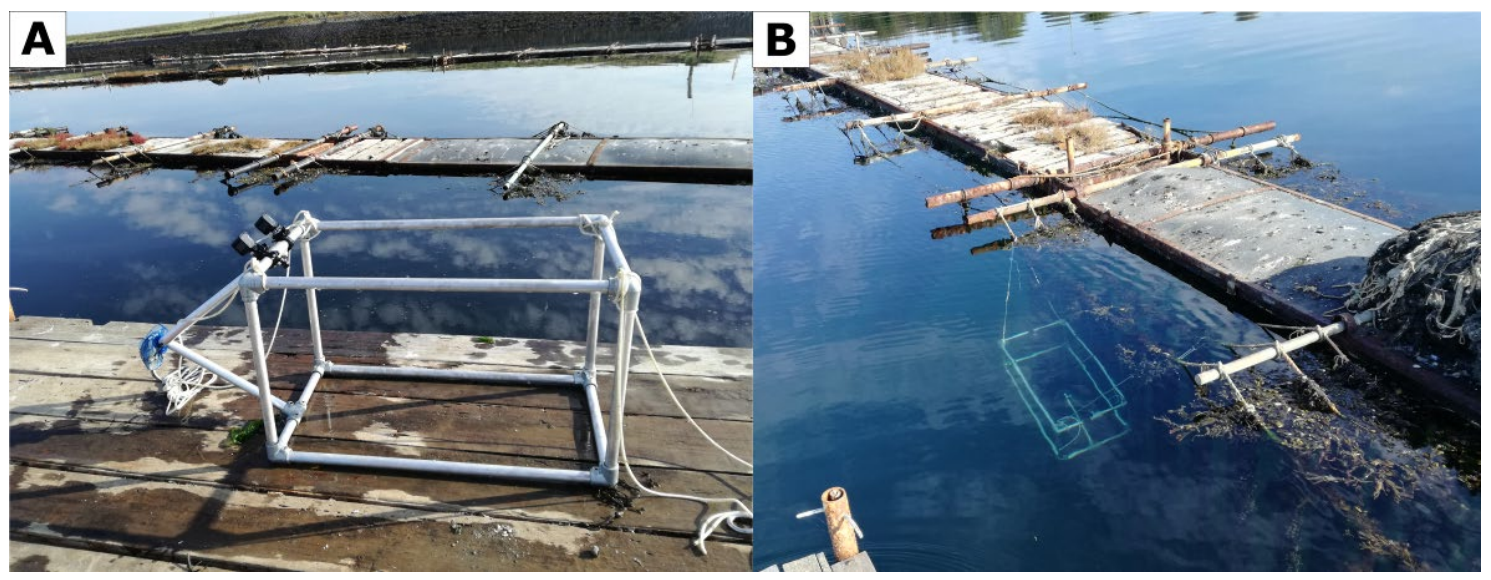

Figure 3. A. Baited camera rig, including bait arm with bait bag on the left side of the cage and 2 GoPro cameras. B. Deployment of BRUV system at the mussel farm with the bait arm situated inside the cage.

In addition, video transects were performed at study site 1 as a comparison to the BRUV system. Fish surveys were performed with a GoPro Hero 5 session on a pole at approx. $1.5-2 \mathrm{~m}$ depth by means of pulling the boat as slowly as possible by hand along the longlines to avoid disturbance caused by the boat engine. 


\subsubsection{Experimental design study site 1}

For the first test, the BRUV system was deployed on the southeast side on the outer line facing inward towards the seaweed farm on a $45^{\circ}$ angle. The cameras were set to continuous recording and a mixture of fresh oyster meat and frozen shrimp was used as bait. The second run was deployed at the north west side facing inward towards the farm. A 100 m distance between the two sample points was considered as a minimum for independent measurements (Ellis and DeMartini 1995). Although authors have attempted to justify this selection using estimates of current speed, fish density and home ranging behaviour, this value is mostly a wild guess (Griffin et al. 2016).

Additionally, three video transects were conducted along the entire length of the horizontal long lines of the farm ( $\pm 100 \mathrm{~m}$ length).

Transect 1: south to north along the western outer second line (in between outer and second line), continuous video.

Transect 2: north to south along the western outer second line (in between outer and second line), continuous video.

Transect 3: south to north along the western outer second line (in between outer and second line), 360 degrees overview every second buoy (about $10 \mathrm{~m}$ ), continuous video.

\subsubsection{Experimental design study site 2}

During the first test at location 2, the attraction of fish by two different bait types, fresh oysters and frozen shrimp, was compared. The bait was attached in the middle of the cage and the cameras were installed opposite of each other, in front of and behind the bait. In the second test, the time lapse function was compared to the normal video function. The bait consisted of a mix of oysters and shrimp and was attached on the outside of the cage.

\subsubsection{Experimental design study site 3}

The tests performed at location 3 were similar to what had been tested at location 2 . In the first trial, two different baits, fresh oysters and shrimps, were compared. The bait bag was attached on the outside of the cage. In the second test, the time lapse function was compared to the normal video function with the bait being attached on the inside of the cage.

\subsubsection{Video analysis}

Video analysis was performed in GoPro Studio and commenced when the rig stabilised at the sampling depth $(1 \mathrm{~m})$. The individuals captured on camera were identified to the lowest taxonomic level possible. Videos were analysed for: time of first arrival (TFA), the maximum number of individuals present in the field of view in sequential time intervals $(\operatorname{Max} N)$ (fish number was determined to be the maximum number of fish in view at any time during the 15 second analysis periods to avoid duplicate counting), time of $\operatorname{Max} N$ and interactions with bait.

\subsection{Results}

\subsubsection{Mobile fauna in the Eastern Scheldt and North Sea}

About 70 fish species inhabit the Eastern Scheldt (Brand et al. 2016), some of which also breed there (such as garfish, anchovies, viviparous eelpout, pipefish and European bullhead). Many of these species migrate to feed or reproduce and are therefore only seasonally encountered in the Eastern Scheldt. Some adult fish species live in the open sea and migrate into fresh water to spawn. Examples of so-called anadromous fish species are smelt and salmon. Fish that migrate from freshwater to saltwater such as eels, thin lipped grey mullets and European flounders are called catadromous. While some species use seaweed to lay their eggs on (sand smelt), others use it as habitat (goby) or food. Table 3 provides a seasonal overview of the most common fish species in the Eastern Scheldt (Gmelig Meyling et al. 2013). An overview of fish species (138 in total) of the North Sea is provided in supplementary Table 1. Both indigenous (119) and introduced species (19) are found (Bos et al. 
2016). The current study focussed on pelagic species and did not include assessment of the benthic fish species.

Table 3. Overview of fish species in the Eastern Scheldt per season.

Based on data collected by means of diver surveys from stichting Anemoon (Gmelig Meyling et al. 2013). Feed indicates whether species are carnivorous (car), herbivorous (her) or omnivorous (omn).

\begin{tabular}{|c|c|c|c|c|c|c|c|}
\hline Species & Common name & Dutch name & Spring & Summer & Autumn & Winter & Feed \\
\hline Anguilla anguilla & Eel & Paling & $x$ & $x$ & $x$ & & Car \\
\hline Atherina boyeri & Big-scale sand smelt & $\begin{array}{l}\text { t Kleine } \\
\text { Koornaarvis }\end{array}$ & $x$ & $x$ & $x$ & & Omn \\
\hline Atherina presbyter & Sand smelt & Koornaarvis & $x$ & $x$ & $x$ & & Car \\
\hline Belone belone & Garfish & Geep & & $x$ & & & Car \\
\hline Callyonimus lyra & Common dragonet & Pitvis & & $x$ & $x$ & & Car \\
\hline Clupea harengus & Herring & Haring & & $x$ & $x$ & & Car \\
\hline Sprattus sprattus & Sprats & Sprot & & $x$ & $x$ & & Car \\
\hline Engraulis encrasicolus & Anchovies & Ansjovis & & $x$ & & & $\begin{array}{l}\text { Car } \\
\text { (plankton) }\end{array}$ \\
\hline Gadus Morhua & Atlantic cod & $\begin{array}{l}\text { Kabeljauw } \\
\text { (gul) }\end{array}$ & & $x$ & $x$ & & Car \\
\hline Merlangius merlangus & Whiting & Wijting & & & $x$ & & Car \\
\hline Pollachius pollachius & European Pollock & Pollak & & $x$ & $x$ & & Car \\
\hline Trisopterus luscus & Pout & Steenbolk & $x$ & $x$ & $x$ & & Car \\
\hline Ciliata mustela & Fivebeard rockling & $\begin{array}{l}5 \text { dradige } \\
\text { meun }\end{array}$ & & & & $x$ & Car \\
\hline Gasterosteus aculeatus & $\begin{array}{l}\text { Three-spined } \\
\text { stickleback }\end{array}$ & $\begin{array}{l}\text { 3-doornige } \\
\text { stekelbaars }\end{array}$ & & $x$ & $x$ & & $\begin{array}{l}\text { Car } \\
\text { (insects, } \\
\text { fishbrood) }\end{array}$ \\
\hline Chelon labrosus & Thicklip grey mullet & Diklipharder & $x$ & $x$ & $x$ & & Her \\
\hline Liza ramada & Thinlip mullet & Dunlipharder & $x$ & $x$ & $x$ & & Her \\
\hline Osmerus eperlanus & European smelt & Spiering & & & & $x$ & Car \\
\hline Lipophrys pholis & Blenny (or Shanny) & Steenslijmvis & & $x$ & & & Car \\
\hline Parablennius gattorugine & Tompot blenny & $\begin{array}{l}\text { Gehoornde } \\
\text { slijmvis }\end{array}$ & & $x$ & $x$ & & Car \\
\hline Trachurus trachurus & Horse mackerel & Horsmakreel & & $x$ & & & Car \\
\hline Gobius niger & Black goby & $\begin{array}{l}\text { Zwarte } \\
\text { grondel }\end{array}$ & $x$ & $x$ & $\mathrm{x}$ & & Car \\
\hline Pomatoschistus minutus & Sand goby & Dikkopje & & $x$ & & & Car \\
\hline Labrus bergylta & Ballan wrasse & Lipvis & & $x$ & & & Car \\
\hline Dicentrarchus labrax & European bass & Zeebaars & & $x$ & $x$ & & Car \\
\hline Pholis gunnellus & Butterfish & Botervis & $x$ & $x$ & $x$ & $x$ & Car \\
\hline Zoarces viviparus & Viviparous eelpout & Puitaal & $x$ & $x$ & $x$ & $x$ & Car \\
\hline Limanda limanda & Common dab & Schar & & $x$ & $x$ & & Car \\
\hline Platichthys flesus & European flounder & Bot & $x$ & $x$ & $x$ & & Car \\
\hline Pleuronectes platessa & European plaice & Schol & $x$ & $x$ & $x$ & & Car \\
\hline Solea solea & Common sole & Tong & & $x$ & $x$ & & Car \\
\hline Cottus gobio & European bullhead & Zeedonderpad & $x$ & $x$ & $x$ & $x$ & Car \\
\hline Taurulus bubalis & Longspined bullhead & $\begin{array}{l}\text { Groene } \\
\text { zeedonderpad }\end{array}$ & $x$ & $x$ & $x$ & $x$ & Car \\
\hline Cyclopterus lumpus & Lumpfish & Snotolf & $x$ & $x$ & & $x$ & Car \\
\hline Syngnathus & Pipefish & Zeenaald & & $x$ & $x$ & & Car \\
\hline
\end{tabular}




\subsubsection{Baited camera and transects}

\subsubsection{Results study site 1}

The baited remote underwater video system (BRUV) was effective in attracting fish within the first minute of deployment at the seaweed farm site. The fish assemblages were dominated by horse mackerel (Trachurus trachurus, first sighted after $31 \mathrm{sec}$, Fig. 4A) and big-scale sand smelt (Atherina boyeri, first sighted after $20 \mathrm{sec}$, Fig. 4B). Fish number peaked at about 5 to 6 minutes. However from about 3 minutes onwards there was a lot of interaction with the bait bag, especially by the carnivorous horse mackerel as opposed to the omnivorous big-scale sand smelt that did not appear to interact with the bait bag as much. Due to the positioning of the bait bag in combination with the cameras it was difficult to quantify the amount of fish hovering behind the bait bag. Furthermore, the visibility worsened throughout the deployment and therefore the presented number of horse mackerel is likely an underestimation. In addition, three types of jellyfish were identified: sea gooseberry (Pleurobrachia pileus), barrel jellyfish (Rhizostoma pulmo) and moon jellyfish (Aurelia aurita).

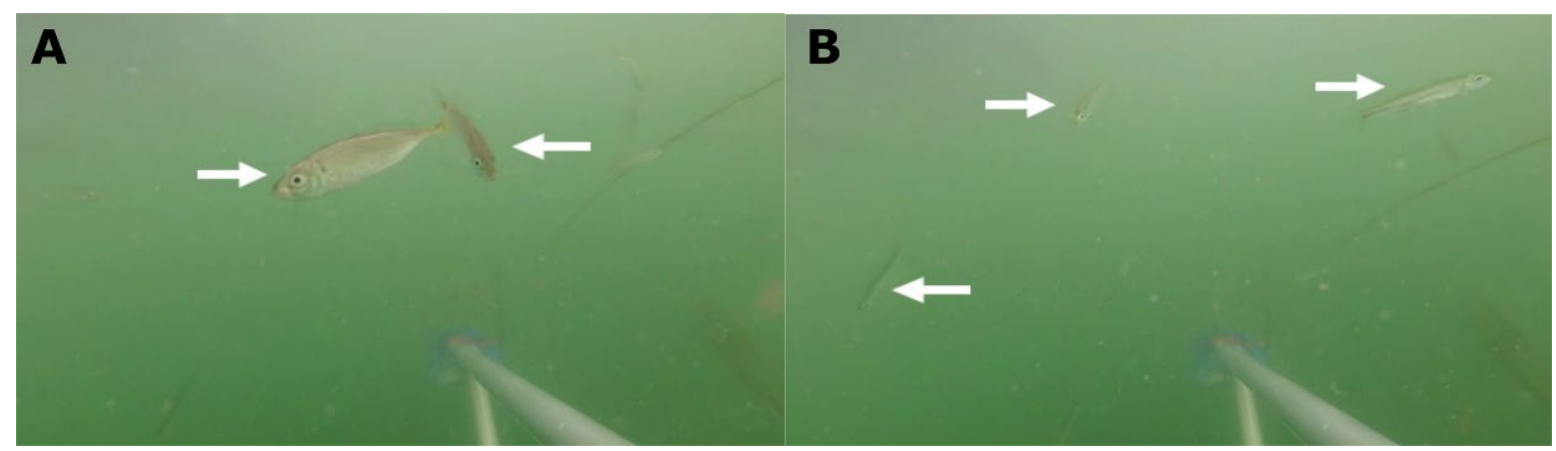

Figure 4. Test run 1 (BRUV system) at seaweed farm of Seaweed Harvest Holland. A. Horse mackerel (white arrows). B. Big-scale sand smelt (white arrow).

The analysed video material of the transects showed big-scale sand smelt (Atherina boyeri) from the moment of immersion. The horse mackerel (Trachurus trachurus), on the other hand, was not observed using this method. Two out of three jellyfish (Pleurobrachia pileus and Aurelia aurita) were also detected with transects. The MaxN of fish in $15 \mathrm{sec}$. time intervals varied along the duration of the transect (approx. 17min) and reached a maximum of 12 individuals (Fig. 5). No other fish species could be identified in the video material, however, small juveniles of approximately $1-2 \mathrm{~cm}$ size travelling in small groups of 4-8 specimens up and down the horizontal longlines were sighted from the surface.

While the boat was pulled along the horizontal lines to film the transects, it regularly got entangled with the vertical droplines from which the seaweed is suspended.

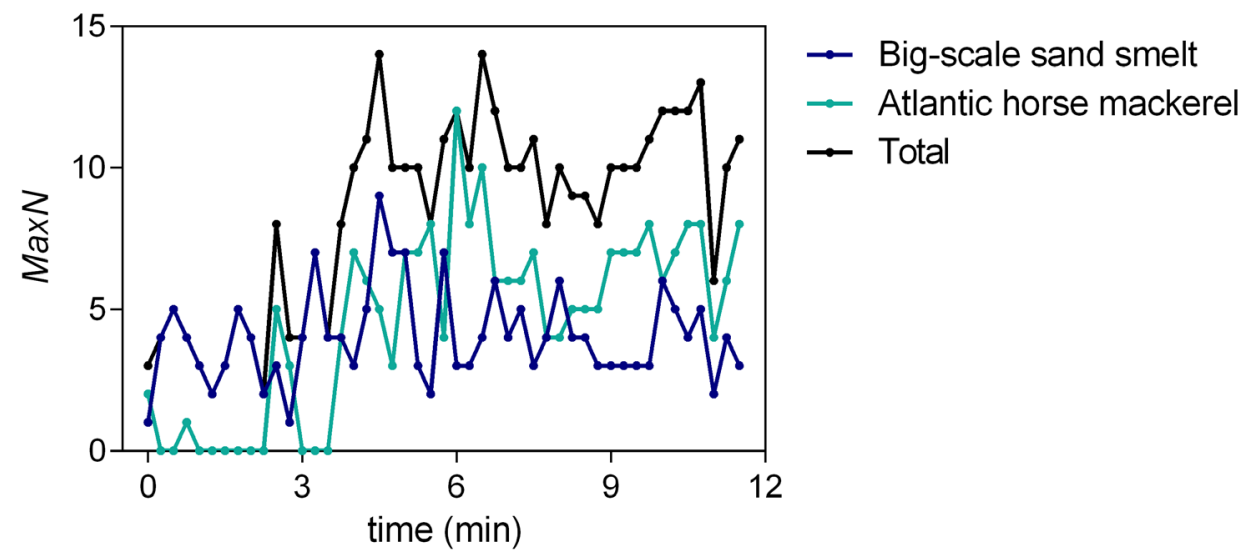

Figure 5. The number of fish is plotted versus time in minutes after deployment of the BRUV. Each data point represents the maximum number of fish (per species and total) visible in the video frame at any one time during a $15 \mathrm{sec}$ interval. 


\subsubsection{Results study site 2}

Based on the preliminary results obtained from the first test at site 1, the following adjustments to the BRUV were made: the bait arm was shortened to a length of $(35 \mathrm{~cm})$ and the cameras were positioned in front of and behind the bait bag by placing the arm and bait bag in the centre of the rig. Visibility in the mussel farm was excellent, but the cage at position 1 was placed unfavourably, as the bait was touching the mussel lines (Fig. 6A+B) which partly blocked the view behind the bait bag. Although some small fish were spotted, they did not seem to be attracted by the bait and were too far away to be identified (Fig. 6C). This is likely to be related to the time of year, late in the summer season. Therefore, no comparison could be made between the two different types of bait or the positioning of the bait bag. However, the positioning of the cameras on opposite sides of the bait was assessed positively, as it provided a clear view of the area behind the bait bag. The quality and evaluation of video material was better than of the time lapse photos. Next to the fish, crabs (Fig. 6A) and jellyfish (Fig. 6B) were observed in the videos.

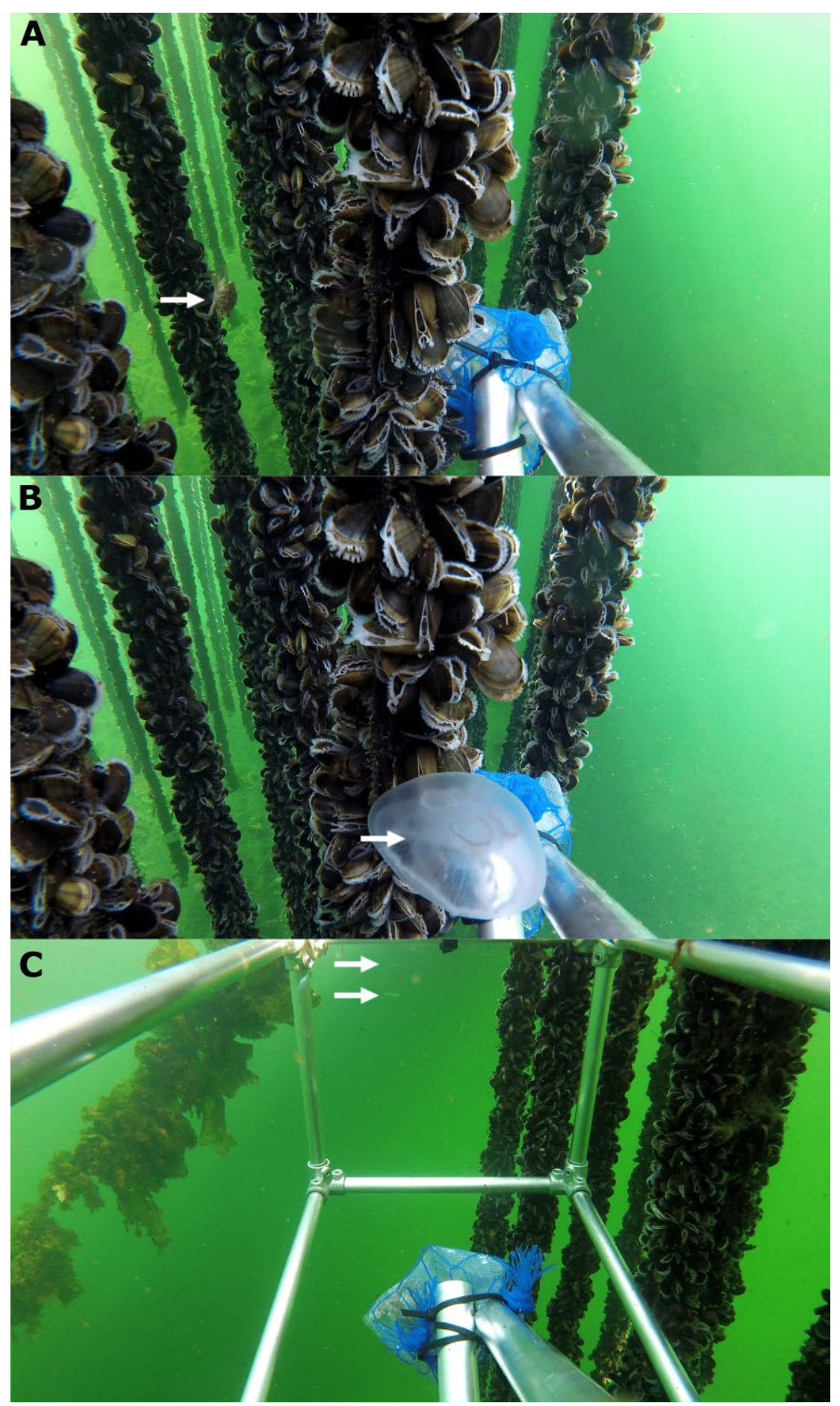

Figure 6. Test run 2 with BRUV at mussel farm 't Zijpe. A. Unfavourably placed cage, crab (white arrow). B. Jellyfish (white arrow). C. Small fish passing by in the background (white arrow). 


\subsubsection{Results study site 3}

The visibility in the harbour was sufficient at the beginning of the trials (Fig. 7A+B), but decreased rapidly during the tests up to a point where the bait could not be seen clearly anymore (Fig. 7C). No fish were spotted and therefore no comparison could be made between the two different types of bait or the positioning of the bait bag. However, crabs could be observed on the bottom (Fig. 7A). Furthermore, the use of shrimp as a bait attracted other shrimps that were gathering on the bait bag (Fig. 7B), whereas shrimp were not observed when oysters were used as a bait.

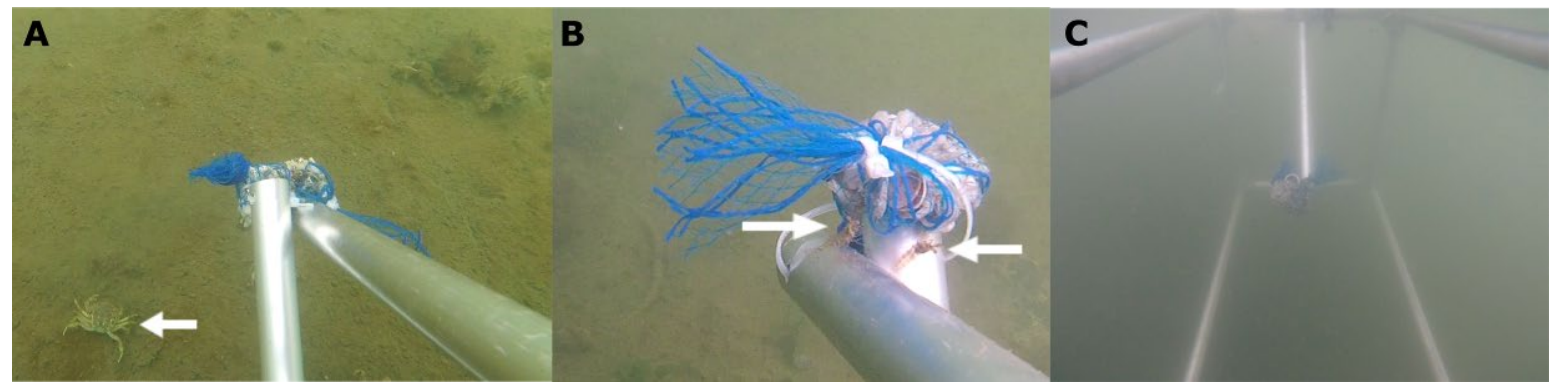

Figure 7. Test run 3 at the yacht harbour in Yerseke. A. Crab (white arrow). B. Shrimp attracted by the bait (white arrows). C. Decreased visibility at test site in the second half of the trials.

A summary of the preliminary tests performed on the three study sites is shown in Table 4 .

Table 4. Summary of the performed tests using baited remote underwater video systems and video transects to study mobile fauna.

\begin{tabular}{|c|c|c|c|c|c|c|c|c|c|c|}
\hline Study & $\begin{array}{l}\text { Video } \\
\text { system }\end{array}$ & Location & Date & $\begin{array}{l}\text { Depth } \\
\text { (m) }\end{array}$ & $\begin{array}{l}\text { Visibility } \\
\text { (m) }\end{array}$ & Bait & $\begin{array}{l}\text { Bait } \\
\text { position }\end{array}$ & $\begin{array}{l}\text { Camera } \\
\text { setting }\end{array}$ & Advantages & Shortcomings \\
\hline 1.1 & BRUV & $\begin{array}{l}\text { Seaweed } \\
\text { farm }\end{array}$ & $\begin{array}{l}22 / 08 / \\
18\end{array}$ & $6-8$ & $0.5-1.5$ & $\begin{array}{l}\text { Oysters \& } \\
\text { shrimp }\end{array}$ & Outside & Video & $\begin{array}{l}\text { Different fish } \\
\text { and jellyfish } \\
\text { species visible }\end{array}$ & $\begin{array}{l}\text { Difficulty to quantify } \\
\text { fish behind the bait } \\
\text { bag }\end{array}$ \\
\hline 1.2 & BRUV & $\begin{array}{l}\text { Seaweed } \\
\text { farm }\end{array}$ & $\begin{array}{l}22 / 08 / \\
18\end{array}$ & $6-8$ & $0.5-1.5$ & $\begin{array}{l}\text { Oysters \& } \\
\text { shrimp }\end{array}$ & Outside & Video & $\begin{array}{l}\text { Different fish } \\
\text { and jellyfish } \\
\text { species visible }\end{array}$ & $\begin{array}{l}\text { Difficulty to quantify } \\
\text { fish behind the bait } \\
\text { bag }\end{array}$ \\
\hline 1.3 & $\begin{array}{l}\text { Video } \\
\text { transects }\end{array}$ & $\begin{array}{l}\text { Seaweed } \\
\text { farm }\end{array}$ & $\begin{array}{l}22 / 08 / \\
18\end{array}$ & $6-8$ & $0.5-1.5$ & - & - & Video & $\begin{array}{l}\text { Fish observed } \\
\text { directly after } \\
\text { immersion }\end{array}$ & $\begin{array}{l}\text { Fewer fish and } \\
\text { jellyfish species } \\
\text { observed than by the } \\
\text { BRUV system; } \\
\text { Difficulty to pull the } \\
\text { boat }\end{array}$ \\
\hline 2.1 & BRUV & $\begin{array}{l}\text { Mussel } \\
\text { farm }\end{array}$ & $\begin{array}{l}16 / 10 / \\
18\end{array}$ & $6-7$ & $>5$ & $\begin{array}{l}\text { Rig 1: } \\
\text { Oysters } \\
\text { Rig 2: } \\
\text { Shrimp }\end{array}$ & Inside & Video & $\begin{array}{l}\text { Excellent } \\
\text { visibility; } \\
\text { Good view on } \\
\text { both sides of } \\
\text { the bait bag }\end{array}$ & $\begin{array}{l}\text { No fish attracted by } \\
\text { the bait; } \\
\text { Cage position } \\
\text { unfavourable (too } \\
\text { close to mussel line) }\end{array}$ \\
\hline 2.2 & BRUV & $\begin{array}{l}\text { Mussel } \\
\text { farm }\end{array}$ & $\begin{array}{l}16 / 10 / \\
18\end{array}$ & $6-7$ & $>5$ & Mix & Outside & $\begin{array}{l}\text { 1: Time } \\
\text { lapse } \\
\text { 2: Video }\end{array}$ & $\begin{array}{l}\text { Excellent } \\
\text { visibility }\end{array}$ & $\begin{array}{l}\text { No fish attracted by } \\
\text { the bait; } \\
\text { Analysis of video } \\
\text { material preferable to } \\
\text { time lapse photos }\end{array}$ \\
\hline 3.1 & BRUV & $\begin{array}{l}\text { Yacht } \\
\text { harbour } \\
\text { Yerseke }\end{array}$ & $\begin{array}{l}09 / 11 / \\
18\end{array}$ & 2 & $0.5-2$ & $\begin{array}{l}\text { Rig 1: } \\
\text { Oysters } \\
\text { Rig 2: } \\
\text { Shrimp }\end{array}$ & Outside & Video & $\begin{array}{l}\text { Shrimp } \\
\text { attracted by the } \\
\text { shrimp bait bag }\end{array}$ & $\begin{array}{l}\text { No fish attracted by } \\
\text { the bait; } \\
\text { Decreasing visibility } \\
\text { during trial }\end{array}$ \\
\hline 3.2 & BRUV & $\begin{array}{l}\text { Yacht } \\
\text { harbour } \\
\text { Yerseke }\end{array}$ & $\begin{array}{l}09 / 11 / \\
18\end{array}$ & 2 & $0.5-2$ & Mix & Inside & $\begin{array}{l}\text { 1: Time } \\
\text { lapse } \\
\text { 2: Video }\end{array}$ & & $\begin{array}{l}\text { No fish attracted by } \\
\text { the bait; } \\
\text { Decreasing visibility }\end{array}$ \\
\hline
\end{tabular}


during trial;

Analysis of video

material preferable to

time lapse photos 


\section{$4 \quad$ Workshop "Use of advanced tools and video techniques for monitoring and quantification in aquatic environments"}

In order to improve our understanding of video technique related activities within WMR, current advancements and limitations, a workshop entitled "Use of advanced tools and video techniques for monitoring and quantification in aquatic environments" was held at Wageningen Marine Research in Ijmuiden. The aim of workshop was to share knowledge and experience between WMR colleagues working in this field, to identify common knowledge gaps and define where we can help and learn from each other. Ideas and experiences on the following topics were shared: 1) research questions, 2) currently used video techniques/equipment, 3) methods and tools for image analysis, 4) techniques and tools needed in the future and 5) sharing of ideas and future development within WMR. An overview of the research questions of existing projects has been created.

The main outcomes of the workshop were:

1) > 38 WMR colleagues use image analysis in their research

2) Exchange of knowledge and experiences within WMR is currently limited

3) Data analyses is time-consuming and often prevents progress

Other outcomes are summarized here:

- Automatic analysis for static images (area cover etc.) is further advanced than for videos. Issues with reflection during the use of spy cameras can be solved by adjusting the angle of incoming light and camera settings.

- Species identification is difficult, as no tools are available yet for this purpose. Even analysis of video images by experts remains difficult and gives variable results. It is, however, a longterm goal in many projects.

- An involvement of Citizen Science (e.g. recreational fisherman) could be considered.

- In turbid areas, acoustic cameras (such as DIDSON) can be of great use, especially for studies on fish behaviour (Martignac et al. 2015).

- GoPro cameras are cheap and widely used but they have restrictions in image quality and are limited in the available settings. Additionally, the processing of GoPro videos needs highperformance computers.

- Computer strength is, in general, currently a limitation for editing video material.

- There is a group in Wageningen that could be helpful in editing of video material (ask communication for contacts).

- All video material can be stored at central location (W: \IMARES\Data\UWvideobank)

- Adobe Premiere Pro, After effects, Davince Resolve and Vegas Pro have been recommended as software for analysis and editing of video material.

The following actions originated from ideas expressed in the workshop:

- Creation of a 'video' community within WMR for low profile sharing of experiences and/or platform to ask questions in form of an intranet forum.

- Application for purchase of a high performance computer including appropriate software for common use. 


\section{$5 \quad$ Conclusions and recommendations}

This study provided promising results for the use of BRUV systems to study marine mobile fauna in seaweed and mussel farms in the Eastern Scheldt.

\subsection{Methods for studying marine mobile fauna}

When it comes to interpreting the results obtained by video techniques, it is crucial to consider the potential bias that is introduced by the chosen method. A BRUV system is more likely to attract carnivorous fish than herbivorous species (Cappo et al. 2007) and our results show a clear difference in the interaction with the bait bag between omnivorous and carnivorous fish species. These observations are supported by the result of the line transect where only the big-scale smelt was detected. BRUV systems therefore have the potential to attract carnivorous fish in the vicinity of the seaweed farm that may be missed by regular line transects. But BRUV systems are not limited to carnivorous species. In our study (site 1), we were able to detect the big-scale smelt, an omnivorous fish species that showed less interaction with the bait bag, but was still attracted by the BRUV set-up. Based on the results at site 1, the suggested optimal deployment time is at least 20 minutes. The current study was a preliminary investigation on the potential use of video techniques for monitoring biodiversity in and around aquaculture farms. For quantification, more tests at different locations are necessary to determine, among others, the optimal deployment time, positioning of BRUV within the farm, and compare farm versus reference sites. Due to the lack of fish abundance at site 2 and 3 we were not able to assess the effect of different types of bait on the detected fish assemblage nor was it possible to compare time-lapse versus continuous film settings.

Seaweeds typically act as a nursery ground for juvenile fish (Steneck et al. 2002). Therefore, a majority of the fish expected to occur in seaweed farms is likely to be of smaller size. This could have potential implications for the use of the BRUV system which is rather suitable for larger pelagic species. Depending on the positioning of the baited camera system in the water column, which in our case was about 1 meter under the water surface, the observation focusses on different species assemblies, i.e. pelagic species as opposed to demersal fish (Mallet and Pelletier 2014). As seaweed farms may also have an effect on the benthic community of fish, for instance through changes in the sediment composition resulting from detached seaweed fragments, it is important to include an assessment of the benthic biodiversity into future studies. For this purpose, BRUV systems could also be placed on the sea bottom.

Besides underwater video systems, complex techniques such as aerial and multispectral imagery have been applied successfully in first trials to study wild macroalgal communities (Brodie et al. 2018). Furthermore, LiDAR (light detection and ranging) and sonar techniques have been used to investigate marine habitats (Young et al. 2015). At present we lack the expertise to implement these techniques but in the future, effort should be directed towards implementation of these techniques to study the impacts and ecosystem services of seaweed aquaculture.

\subsection{Environmental factors affecting the use of cameras}

Low visibility $(<0.5 \mathrm{~m}$ ) can be an issue when using video techniques, both in the Eastern Scheldt and the North Sea, as it impedes the detection of all specimens and identification of fish species. Visibility is linked to currents, tides, wind condition and season. Our results indicate that the best visibility is achieved during turning of the tides, which has to be considered for future experimentation with video systems. 
But not only visibility is affected by the tidal conditions. Also the fish presence and abundance can vary with the tides (Childs et al. 2008, Meynecke et al. 2008). While juvenile fish tend to stay in the seaweed farm during low tide, larger pelagic fish move away to nearby natural habitats, such as seagrass and kelp beds. Thus, the highest fish abundance in coastal areas is expected during incoming high tide, whereas less fish are seen during low tide. However, fish behaviour also depends on the local conditions and nearby habitat structure.

Seasonality is another important component affecting fish abundance (Supplementary Table 1). After September, fish abundance is too low for BRUV deployment, as was demonstrated during our measurements at test sites 2 and 3. Furthermore, in a seaweed cultivation site in Ireland, it was shown that most of the mackerel and pollack juveniles that are generally found in the farm, have moved away by September. Wrasse, on the other hand, a benthic species that does not swim upwards to the cultivation lines, still occurs below the seaweed farm at that time (pers. comm. Jose FariñasFranco). The optimal time point for deployment of a BRUV system has to be chosen based on the seasonal occurrence of fish (Supplementary Table 1). But generally, most fish are expected when the seaweed biomass is highest, as larger seaweeds provide a more versatile habitat. Similarly, fish abundance in mussel farms shows a seasonal variation, with lower abundance in winter and an increase over summer (Morrisey et al. 2006)

\subsection{Recommendations for the optimization of BRUV systems, deployment and experimental design}

Timing. As biodiversity is likely to change over the season, the time point of the experiment has a crucial effect on the observed fish assembly. It is recommended to choose the appropriate season (see Table 3) and standardization is needed in regard to tidal condition (different fish species could be seen during high and low tide). High seaweed biomass is also favourable as it increases the versatility of the habitat and could therefore lead to higher species numbers. Furthermore, wind speed should be less than 10 knots (4 Beaufort) on the day of deployment.

Visibility. Visibility affects the use of video recordings. There are multiple factors that affect visible, for instance location, current speed, season, or related to tides. Turbidity is optimal during the turning of the tides, so the aim should be to deploy around high or low slack tide. For comparability visibility should be measured in future studies for instance by means of a Secchi disk or turbidity meters.

Rig design. Inshore seaweed farms are expected to attract a different type (ratio) of fish than offshore (more smaller and juvenile fish versus larger predators but also juveniles). The BRUV rig is originally designed to detect larger predatory fish. The bait arm could be shortened in order to achieve more accurate estimation of smaller sized fish attracted to the bait bag in low visibility conditions. When the arm is placed inside of the cage in order to record both sides of the bait bag, the steering/positioning in the water is potentially less optimal, especially in conditions where currents thrive or when less points of attachment of the BRUV are possible, this will affect the positioning.

Attachment of the rig. In this study, the BRUV system has been attached by ropes and 4 karabiners to the horizontal seaweed or mussel cultivation lines. However, at control sites, these lines are not always available and other attachment and deployment methods have to be developed. A different design in which the rig can be attached by one or two points (without losing stability/or changes in direction) or be attached to a buoy could be possible solutions, and should be tested, for the rig deployment at control sites. Easy attachment methods will also facilitate a more rapid deployment when several locations have to be filmed.

Bait type. A combination of different types of bait is recommended for future studies. Whereas oyster meat was effective in attracting a carnivorous and omnivorous fish species, shrimp were attracted by the use of shrimp baits. A combination is likely to attract the highest number of different species. 
Combination of BRUV systems with other methods. BRUV systems should be combined with other methods in order to decrease the bias that is introduced by the use of bait. These can be either other video techniques, such as non-baited remote cameras or diver operated cameras. On the other hand, BRUV observations could also be coupled with molecular biology techniques, such as environmental DNA sampling, or traditional methods such as traps and/or nets for validation.

Reproducibility. Finally, the chosen study set-up depends on the research question. In order to obtain reliable and valuable information on the ecosystem service of seaweed farms in terms of attracting fish assemblies, experiments have to be performed repeatedly (replicates) and control sites have to be included, for instance by installing a BRUV system outside of the seaweed farm or in a natural seaweed habitat.

A reliable, validated and standardized design for a BRUV system will open new opportunities to study the mobile fauna associated to fish and mussel farms and could result in monitoring programs to support careful management of marine resources.

\section{Acknowledgements}

We would like to thank Julia Wald, John van Leeuwen and other personnel from Seaweed Harvest Holland for access and assistance at their seaweed farm at the Schelpenhoek. We would like to thank Erik Veerhoek from Mosselkwekerij Veerhoek, Bruinisse for the opportunity to deploy our camera system at his mussel farm and use of his raft and Jan van der Wijk for access to Yerseke jachthaven. Finally we would like to thank Jose Maria Fariñas-Franco for discussions on baited camera use and helpful insights. 


\section{$7 \quad$ Quality Assurance}

Wageningen Marine Research utilises an ISO 9001:2015 certified quality management system. This certificate is valid until 15 December 2021. The organisation has been certified since 27 February 2001. The certification was issued by DNV GL.

Furthermore, the chemical laboratory at IJmuiden has NEN-EN-ISO/IEC 17025:2005 accreditation for test laboratories with number L097. This accreditation is valid until $1^{\text {th }}$ of April 2021 and was first issued on 27 March 1997. Accreditation was granted by the Council for Accreditation. The chemical laboratory at IJmuiden has thus demonstrated its ability to provide valid results according a technically competent manner and to work according to the ISO 17025 standard. The scope (L097) of de accredited analytical methods can be found at the website of the Council for Accreditation (www.rva.nl).

On the basis of this accreditation, the quality characteristic $Q$ is awarded to the results of those components which are incorporated in the scope, provided they comply with all quality requirements. The quality characteristic $\mathrm{Q}$ is stated in the tables with the results. If, the quality characteristic $\mathrm{Q}$ is not mentioned, the reason why is explained.

The quality of the test methods is ensured in various ways. The accuracy of the analysis is regularly assessed by participation in inter-laboratory performance studies including those organized by QUASIMEME. If no inter-laboratory study is available, a second-level control is performed. In addition, a first-level control is performed for each series of measurements.

In addition to the line controls the following general quality controls are carried out:

- Blank research.

- Recovery.

- Internal standard

- Injection standard.

- Sensitivity.

The above controls are described in Wageningen Marine Research working instruction ISW 2.10.2.105. If desired, information regarding the performance characteristics of the analytical methods is available at the chemical laboratory at IJmuiden.

If the quality cannot be guaranteed, appropriate measures are taken. 


\section{References}

Barnes, H. 1952. Under-Water Television and Marine Biology. Nature. 169:477-9.

Bos, O.G., Gittenberger, A., Boois, I.J. de, Asch, M. van, Wal, J.T. van der, Cremer, J., Hoorn, B. van der et al. 2016. Soortenlijst Nederlandse Noordzee. 99.

Brand, A.D., Kothuis, B.L.M. \& Prooijen, B.C. Van 2016. The Eastern Scheldt Survey.

Brodie, J., Ash, L. V, Tittley, I. \& Yesson, C. 2018. A comparison of multispectral aerial and satellite imagery for mapping intertidal seaweed communities. Aquat. Conserv. Mar. Freshw. Ecosyst. 872-81.

Burge, E.J., Atack, J.D., Andrews, C., Binder, B.M., Hart, Z.D., Wood, A.C., Bohrer, L.E. et al. 2012. Underwater video monitoring of groupers and the associated hard-bottom reef fish assemblage of North Carolina. Bull. Mar. Sci. 88:15-38.

Callier, M.D., Byron, C.J., Bengtson, D.A., Cranford, P.J., Cross, S.F., Focken, U., Jansen, H.M. et al. 2018. Attraction and repulsion of mobile wild organisms to finfish and shellfish aquaculture: a review. Rev. Aquac. 10:924-49.

Cappo, M., De'ath, G. \& Speare, P. 2007. Inter-reef vertebrate communities of the Great Barrier Reef Marine Park determined by baited remote underwater video stations. Mar. Ecol. Prog. Ser. 350:209-21.

Childs, A.R., Cowley, P.D., Næsje, T.F., Booth, A.J., Potts, W.M., Thorstad, E.B. \& Økland, F. 2008. Do environmental factors influence the movement of estuarine fish? A case study using acoustic telemetry. Estuar. Coast. Shelf Sci. 78:227-36.

Colton, M.A. \& Swearer, S.E. 2010. A comparison of two survey methods: Differences between underwater visual census and baited remote underwater video. Mar. Ecol. Prog. Ser.

De Vos, L., Götz, A., Winker, H. \& Attwood, C.G. 2014. Optimal BRUVs (baited remote underwater video system) survey design for reef fish monitoring in the Stilbaai Marine Protected Area. African J. Mar. Sci.

Dealteris, J.T., Kilpatrick, B.D. \& Rheault, R.B. 2004. A comparative evaluation of the habitat value of shellfish aquaculture gear, sumerged aquatic vegetation and a non-vegetated seabed. J. Shellfish Res. 23:867-74.

Dunbrack, R. \& Zielinski, R. 2003. Seasonal and diurnal activity of sixgill sharks (Hexanchus griseus) on a shallow water reef in the Strait of Georgia, British Columbia. Can. J. Zool. 81:1107-11.

Ellis, D.M. \& DeMartini, E.E. 1995. Evaluation of a video camera technique for indexing abundances of juvenile pink snapper, Pristipomoides filamentosus, and other Hawaiian insular shelf fishes. Fish. Bull. 93:67-77.

Fedra, K. \& Machan, R. 1979. A Self-Contained Underwater Time-Lapse Camera for in situ Long-Term Observations. Mar. Biol. 55:239-46.

Gladstone, W., Lindfield, S., Coleman, M. \& Kelaher, B. 2012. Optimisation of baited remote underwater video sampling designs for estuarine fish assemblages. J. Exp. Mar. Bio. Ecol.

Gmelig Meyling, A.W., Lente, I. van der, Schrieken, N., Gittenberrger, A. \& De Bruyne, R.H. 2013. Het Duiken Gebruiken 3: Gegevensanalyse van het Monitoringproject Onderwater Oever (MOO).

Grabowski, T.B., Boswell, K.M., McAdam, B.J., Wells, R.J.D. \& Marteinsdóttir, G. 2012. Characterization of Atlantic Cod Spawning Habitat and Behavior in Icelandic Coastal Waters. PLoS One. 7.

Griffin, R.A., Robinson, G.J., West, A., Gloyne-Phillips, I.T. \& Unsworth, R.K.F. 2016. Assessing fish and motile fauna around offshore windfarms using stereo baited video. PLoS One. 11:1-14.

Harvey, E.S., Cappo, M., Butler, J.J., Hall, N. \& Kendrick, G.A. 2007. Bait attraction affects the performance of remote underwater video stations in assessment of demersal fish community structure. Mar. Ecol. Prog. Ser.

Jan, R.Q., Shao, Y.T., Lin, F.P., Fan, T.Y., Tu, Y.Y., Tsai, H.S. \& Shao, K.T. 2007. An underwater camera system for Real-Time coral reef fish monitoring. Raffles Bull. Zool. 2014:273-9.

Langlois, T.J., Harvey, E.S., Fitzpatrick, B., Meeuwig, J.J., Shedrawi, G. \& Watson, D.L. 2010. Cost-efficient sampling of fish assemblages: Comparison of baited video stations and diver video transects. Aquat. Biol. 9:155-68.

Mallet, D. \& Pelletier, D. 2014. Underwater video techniques for observing coastal marine biodiversity: A review of sixty years of publications (1952-2012).

Mallet, D., Wantiez, L., Lemouellic, S., Vigliola, L. \& Pelletier, D. 2014. Complementarity of rotating video and underwater visual census for assessing species richness, frequency and density of reef fish on coral reef slopes. PLoS One.

Martignac, F., Daroux, A., Bagliniere, J.L., Ombredane, D. \& Guillard, J. 2015. The use of acoustic cameras in shallow waters: New hydroacoustic tools for monitoring migratory fish population. A review of DIDSON 
technology. Fish Fish. 16:486-510.

McKindsey, C.W., Thetmeyer, H., Landry, T. \& Silvert, W. 2006. Review of recent carrying capacity models for bivalve culture and recommendations for research and management. Aquaculture. 261:451-62.

Meynecke, J.O., Poole, G.C., Werry, J. \& Lee, S.Y. 2008. Use of PIT tag and underwater video recording in assessing estuarine fish movement in a high intertidal mangrove and salt marsh creek. Estuar. Coast. Shelf Sci. 79:168-78.

Morrisey, D.J., Cole, R.G., Davey, N.K., Handley, S.J., Bradley, A., Brown, S.N. \& Madarasz, A.L. 2006. Abundance and diversity of fish on mussel farms in New Zealand. Aquaculture. 252:277-88.

Munro, J.L. 1974. The mode of operation of Antillean fish traps and the relationships between ingress, escapement, catch and soak. ICES J. Mar. Sci. 35:337-50.

Murphy, H.M. \& Jenkins, G.P. 2010. Observational methods used in marine spatial monitoring of fishes and associated habitats: A review. Mar. Freshw. Res.

O'Connell, A.F., Nichols, J.D. \& Karanth, K.U. 2011. Camera traps in animal ecology: Methods and analyses. $1-271 \mathrm{pp}$.

Pelletier, D. 2011. Indicators - Constructing and validating indicators of the effectiveness of marine protected areas. 247-290 pp.

Pelletier, D., Leleu, K., Mallet, D., Mou-Tham, G., Hervé, G., Boureau, M. \& Guilpart, N. 2012. Remote highdefinition rotating video enables fast spatial survey of marine underwater macrofauna and habitats. PLoS One. 7:1-13.

Pita, P., Fernández-Márquez, D. \& Freire, J. 2014. Short-term performance of three underwater sampling techniques for assessing differences in the absolute abundances and in the inventories of the coastal fish communities of the Northeast Atlantic Ocean. Mar. Freshw. Res.

Poelman, M. 2019. Proposal: Marine Resources (to support Blue Growth)

Santana-Garcon, J., Newman, S.J. \& Harvey, E.S. 2014. Development and validation of a mid-water baited stereo-video technique for investigating pelagic fish assemblages. J. Exp. Mar. Bio. Ecol.

Silver, S.C., Ostro, L.E.T., Marsh, L.K., Maffei, L., Noss, A.J., Kelly, M.J., Wallace, R.B. et al. 2004. The use of camera traps for estimating jaguar Panthera onca abundance and density using capture/recapture analysis. Oryx. 38:148-54.

Spencer, M.L., Stoner, A.W., Ryer, C.H. \& Munk, J.E. 2005. A towed camera sled for estimating abundance of juvenile flatfishes and habitat characteristics: Comparison with beam trawls and divers. Estuar. Coast. Shelf Sci. 64:497-503.

Steneck, R.S., Graham, M.H., Bourque, B.J., Corbett, D., Erlandson, J.M., Estes, J.A. \& Tegner, M.J. 2002. Kelp forest ecosystems: Biodiversity, stability, resilience and future. Environ. Conserv. 29:436-59.

Stobart, B., Díaz, D., Álvarez, F., Alonso, C., Mallol, S. \& Goñi, R. 2015. Performance of baited underwater video: Does it underestimate abundance at high population densities? PLoS One.

Stokesbury, K.D.E., Harris, B.P., Marino, M.C. \& Nogueira, J.I. 2004. Estimation of sea scallop abundance using a video survey in off-shore US waters. J. Shellfish Res. 23:33-40.

Watson, D.L., Harvey, E.S., Anderson, M.J. \& Kendrick, G.A. 2005. A comparison of temperate reef fish assemblages recorded by three underwater stereo-video techniques. Mar. Biol.

Watson, D.L., Harvey, E.S., Fitzpatrick, B.M., Langlois, T.J. \& Shedrawi, G. 2010. Assessing reef fish assemblage structure: How do different stereo-video techniques compare? Mar. Biol. 157:1237-50.

Whitmarsh, S.K., Fairweather, P.G. \& Huveneers, C. 2017. What is Big BRUVver up to? Methods and uses of baited underwater video.

Williams, K., De Robertis, A., Berkowitz, Z., Rooper, C. \& Towler, R. 2014. An underwater stereo-camera trap. Methods Oceanogr.

Wood, D., Capuzzo, E., Kirby, D., Mooney-mcauley, K. \& Kerrison, P. 2017. UK macroalgae aquaculture: What are the key environmental and licensing considerations? Mar. Policy. 83:29-39.

Wraith, J.A. 2007. Assessing reef fish assemblages in a temperate marine park using baited remote underwater video. University of Wollongong.

Young, M., Ierodiaconou, D. \& Womersley, T. 2015. Forests of the sea: Predictive habitat modelling to assess the abundance of canopy forming kelp forests on temperate reefs. Remote Sens. Environ. 170:178-87. 


\section{Justification}

Report C017/19

Project Number: 431800099

The scientific quality of this report has been peer reviewed by a colleague scientist and a member of the Management Team of Wageningen Marine Research

Approved: $\quad$ Pauline Kamermans

Signature:

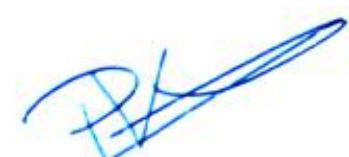

Date:

$19 / 02 / 2019$

Approved: $\quad$ Drs. J. Asjes

Manager Integration

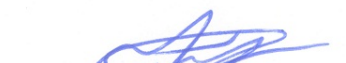

Signature:

Date:

$19 / 02 / 2019$ 


\section{Annex 1 Supplementary Table}

Supplementary Table 1. Overview of fish species in the North Sea.

Data retrieved from Bos et al. 2016.

\begin{tabular}{|c|c|c|c|c|}
\hline Order & Family & Genus & Species & Dutch name \\
\hline Anguilliformes & Congridae & Conger & Conger conger & Paling \\
\hline Atheriniformes & Atherinidae & Atherina & Atherina boyeri & Kongeraal \\
\hline Atheriniformes & Atherinidae & Atherina & Atherina presbyter & Kleine koornaarvis \\
\hline Beloniformes & Belonidae & Belone & Belone belone & Koornaarvis \\
\hline Beloniformes & Scomberesocidae & Scomberesox & Scomberesox saurus & Geep \\
\hline Clupeiformes & Clupeidae & Alosa & Alosa fallax & Makreelgeep \\
\hline Clupeiformes & Clupeidae & Clupea & Clupea harengus & Haring \\
\hline Clupeiformes & Clupeidae & Sardina & Sardina pilchardus & Sardien \\
\hline Clupeiformes & Clupeidae & Sprattus & Sprattus sprattus & Sprot \\
\hline Clupeiformes & Engraulidae & Engraulis & Engraulis encrasicolus & Ansjovis \\
\hline Cyprinodontiformes & Poeciliidae & Lebistes & Lebistes reticulatus & Gupp* \\
\hline Gadiformes & Gadidae & Gadus & Gadus morhua & Kabeljauw \\
\hline Gadiformes & Gadidae & Melanogrammus & Melanogrammus aeglefinus & Schelvis* \\
\hline Gadiformes & Gadidae & Merlangius & Merlangius merlangus & Wijting \\
\hline Gadiformes & Gadidae & Micromesistius & Micromesistius poutassou & Blauwe wijting \\
\hline Gadiformes & Gadidae & Pollachius & Pollachius pollachius & Pollak* \\
\hline Gadiformes & Gadidae & Pollachius & Pollachius virens & Koolvis* \\
\hline Gadiformes & Gadidae & Raniceps & Raniceps raninus & Vorskwab \\
\hline Gadiformes & Gadidae & Trisopterus & Trisopterus esmarki & Kever* \\
\hline Gadiformes & Gadidae & Trisopterus & Trisopterus luscus & Steenbolk \\
\hline Gadiformes & Gadidae & Trisopterus & Trisopterus minutus & Dwergbolk \\
\hline Gadiformes & Lotidae & Ciliata & Ciliata mustela & Vijfdradige meun \\
\hline Gadiformes & Lotidae & Ciliata & Ciliata septentrionalis & Noorse meun \\
\hline Gadiformes & Lotidae & Enchelyopus & Enchelyopus cimbrius & Vierdradige meun \\
\hline Gadiformes & Lotidae & Gaidropsarus & Gaidropsarus vulgaris & Driedradige meun \\
\hline Gadiformes & Lotidae & Molva & Molva molva & Leng \\
\hline Gadiformes & Merlucciidae & Merluccius & Merluccius merluccius & Heek \\
\hline Gadiformes & Phycidae & Phycis & Phycis blennoides & Gaffelkabeljauw \\
\hline Gasterosteiformes & Gasterosteidae & Gasterosteus & Gasterosteus aculeatus & \\
\hline Gasterosteiformes & Gasterosteidae & Spinachia & Spinachia spinachia & Zeestekelbaars \\
\hline Lampriformes & Lampridae & Lampris & Lampris guttatus & Koningsvis \\
\hline Lophiiformes & Lophiidae & Lophius & Lophius piscatorius & Zeeduivel \\
\hline Ophidiiformes & Carapidae & Echiodon & Echiodon drummondi & Parelvis* \\
\hline Osmeriformes & Argentinidae & Argentina & Argentina sphyraena & Kleine zilversmelt \\
\hline Osmeriformes & Osmeridae & Osmerus & Osmerus eperlanus & \\
\hline Perciformes & Ammodytidae & Ammodytes & Ammodytes marinus & Noorse zandspiering \\
\hline Perciformes & Ammodytidae & Ammodytes & Ammodytes tobianus & Zandspiering \\
\hline Perciformes & Ammodytidae & Gymnammodytes & Gymnammodytes semisquamatus & \\
\hline Perciformes & Ammodytidae & Hyperoplus & Hyperoplus immaculatus & \\
\hline Perciformes & Ammodytidae & Hyperoplus & Hyperoplus lanceolatus & Smelt \\
\hline Perciformes & Anarhichadidae & Anarhichas & Anarhichas lupus & Zeewolf \\
\hline Perciformes & Blenniidae & Lipophrys & Lipophrys pholis & Slijmvis \\
\hline Perciformes & Blenniidae & Parablennius & Parablennius gattorugine & Gehoornde slijmvis \\
\hline Perciformes & Bramidae & Brama & Brama brama & Braam \\
\hline
\end{tabular}




\begin{tabular}{|c|c|c|c|c|}
\hline Perciformes & Callionymidae & Callionymus & Callionymus lyra & Pitvis \\
\hline Perciformes & Callionymidae & Callionymus & Callionymus maculatus & Gevlekte pitvis* \\
\hline Perciformes & Callionymidae & Callionymus & Callionymus reticulatus & Rasterpitvis \\
\hline Perciformes & Caproidae & Capros & Capros aper & Evervis \\
\hline Perciformes & Carangidae & Trachinotus & Trachinotus ovatus & Gaffelmakreel* \\
\hline Perciformes & Carangidae & Trachurus & Trachurus trachurus & Horsmakreel \\
\hline Perciformes & Centrolophidae & Centrolophus & Centrolophus niger & Zwarte vis \\
\hline Perciformes & Gobiidae & Aphia & Aphia minuta & Glasgrondel \\
\hline Perciformes & Gobiidae & Crystallogobius & Crystallogobius linearis & Kristalgrondel* \\
\hline Perciformes & Gobiidae & Gobius & Gobius niger & Zwarte grondel \\
\hline Perciformes & Gobiidae & Gobiusculus & Gobiusculus flavescens & Tweevlekgrondel \\
\hline Perciformes & Gobiidae & Neogobius & Neogobius melanostomus & \\
\hline Perciformes & Gobiidae & Pomatoschistus & Pomatoschistus lozanoi & Lozano's grondel \\
\hline Perciformes & Gobiidae & Pomatoschistus & Pomatoschistus microps & Brakwatergrondel \\
\hline Perciformes & Gobiidae & Pomatoschistus & Pomatoschistus minutus & Dikkopje \\
\hline Perciformes & Gobiidae & Pomatoschistus & Pomatoschistus norvegicus & Noorse grondel* \\
\hline Perciformes & Gobiidae & Pomatoschistus & Pomatoschistus pictus & Kleurige grondel \\
\hline Perciformes & Gobiidae & Thorogobius & Thorogobius ephippiatus & \\
\hline Perciformes & Labridae & Crenilabrus & Crenilabrus bailloni & Baillon's lipvis \\
\hline Perciformes & Labridae & Crenilabrus & Crenilabrus melops & Zwartooglipvis \\
\hline Perciformes & Labridae & Ctenolabrus & Ctenolabrus rupestris & Kliplipvis \\
\hline Perciformes & Labridae & Labrus & Labrus bergylta & Gevlekte lipvis \\
\hline Perciformes & Moronidae & Dicentrarchus & Dicentrarchus labrax & Zeebaars \\
\hline Perciformes & Mugilidae & Chelon & Chelon labrosus & Diklipharder \\
\hline Perciformes & Mugilidae & Liza & Liza aurata & Goudharder \\
\hline Perciformes & Mugilidae & Liza & Liza ramada & Dunlipharder \\
\hline Perciformes & Mullidae & Mullus & Mullus surmuletus & Mul \\
\hline Perciformes & Pholidae & Pholis & Pholis gunnellus & Botervis \\
\hline Perciformes & Sciaenidae & Argyrosomus & Argyrosomus regius & Ombervis \\
\hline Perciformes & Scombridae & Scomber & Scomber japonicus & Spaanse makreel \\
\hline Perciformes & Scombridae & Scomber & Scomber scombrus & Makreel \\
\hline Perciformes & Sparidae & Boops & Boops boops & Bokvis \\
\hline Perciformes & Sparidae & Pagellus & Pagellus acarne & Spaanse zeebrasem \\
\hline Perciformes & Sparidae & Pagellus & Pagellus bogaraveo & Zeebrasem \\
\hline Perciformes & Sparidae & Pagellus & Pagellus erythrinus & \\
\hline Perciformes & Sparidae & Sarpa & Sarpa salpa & Gestreepte bokvis \\
\hline Perciformes & Sparidae & Spondyliosoma & Spondyliosoma cantharus & Zeekarper \\
\hline Perciformes & Stichaeidae & Lumpenus & Lumpenus lampretaeformis & ljslandse bandvis \\
\hline Perciformes & Trachinidae & Echiichthys & Echiichthys vipera & Kleine pieterman \\
\hline Perciformes & Trachinidae & Trachinus & Trachinus draco & Grote pieterman \\
\hline Perciformes & Xiphiidae & Xiphias & Xiphias gladius & Zwaardvis \\
\hline Perciformes & Zoarcidae & Zoarces & Zoarces viviparus & Puitaal \\
\hline Pleuronectiformes & Achiridae & Trinectes & Trinectes maculatus & Hogchoker* \\
\hline Pleuronectiformes & Bothidae & Arnoglossus & Arnoglossus laterna & Schurftvis \\
\hline Pleuronectiformes & Pleuronectidae & Glyptocephalus & Glyptocephalus cynoglossus & Witje \\
\hline Pleuronectiformes & Pleuronectidae & Hippoglossoides & Hippoglossoides platessoides & Lange schar \\
\hline Pleuronectiformes & Pleuronectidae & Hippoglossus & Hippoglossus hippoglossus & Heilbot \\
\hline Pleuronectiformes & Pleuronectidae & Limanda & Limanda limanda & Schar \\
\hline Pleuronectiformes & Pleuronectidae & Microstomus & Microstomus kitt & Tongschar \\
\hline Pleuronectiformes & Pleuronectidae & Platichthys & Platichthys flesus & \\
\hline Pleuronectiformes & Pleuronectidae & Pleuronectes & Pleuronectes platessa & Schol \\
\hline Pleuronectiformes & Scophthalmidae & Lepidorhombus & Lepidorhombus whiffiagonis & Scharrentong \\
\hline
\end{tabular}




\begin{tabular}{|c|c|c|c|c|}
\hline Pleuronectiformes & Scophthalmidae & Phrynorhombus & Phrynorhombus norvegicus & Dwergbot \\
\hline Pleuronectiformes & Scophthalmidae & Scophthalmus & Scophthalmus maximus & Tarbot \\
\hline Pleuronectiformes & Scophthalmidae & Scophthalmus & Scophthalmus rhombus & Griet \\
\hline Pleuronectiformes & Scophthalmidae & Zeugopterus & Zeugopterus punctatus & Gevlekte griet \\
\hline Pleuronectiformes & Soleidae & Buglossidium & Buglossidium luteum & Dwergtong \\
\hline Pleuronectiformes & Soleidae & Microchirus & Microchirus variegatus & Dikrugtong* \\
\hline Pleuronectiformes & Soleidae & Solea & Solea lascaris & Franse tong \\
\hline Pleuronectiformes & Soleidae & Solea & Solea solea & Tong \\
\hline Salmoniformes & Salmonidae & Coregonus & Coregonus lavaretus oxyrinchus & Noordzeehouting* \\
\hline Salmoniformes & Salmonidae & Oncorhynchus & Oncorhynchus kisutch & Zilver zalm* \\
\hline Salmoniformes & Salmonidae & Oncorhynchus & Oncorhynchus mykiss & Regenboog forel* \\
\hline Salmoniformes & Salmonidae & Salmo & Salmo salar & Atlantische zalm* \\
\hline Salmoniformes & Salmonidae & Salmo & Salmo trutta & Bruine of rivier forel* \\
\hline Scorpaeniformes & Agonidae & Agonus & Agonus cataphractus & $\begin{array}{l}\text { Harnasmannetje } \\
\text { Groene }\end{array}$ \\
\hline Scorpaeniformes & Cottidae & Enophrys & Enophrys bubalis & zeedonderpad \\
\hline Scorpaeniformes & Cottidae & Micrenophrys & Micrenophrys lilljeborgii & \\
\hline Scorpaeniformes & Cottidae & Myoxocephalus & Myoxocephalus scorpius & $\begin{array}{l}\text { Zeedonderpad } \\
\text { Murray's }\end{array}$ \\
\hline Scorpaeniformes & Cottidae & Triglops & Triglops murrayi & zeedonderpad* \\
\hline Scorpaeniformes & Cyclopteridae & Cyclopterus & Cyclopterus lumpus & Snotolf \\
\hline Scorpaeniformes & Liparidae & Liparis & Liparis liparis & Slakdolf \\
\hline Scorpaeniformes & Liparidae & Liparis & Liparis montagui & Kleine slakdolf \\
\hline Scorpaeniformes & Sebastidae & Helicolenus & Helicolenus dactylopterus & Blauwkeeltje \\
\hline Scorpaeniformes & Sebastidae & Sebastes & Sebastes marinus & Roodbaars \\
\hline Scorpaeniformes & Sebastidae & Sebastes & Sebastes schlegelii* & \\
\hline Scorpaeniformes & Sebastidae & Sebastes & Sebastes viviparus & Kleine roodbaars \\
\hline Scorpaeniformes & Triglidae & Aspitrigla & Aspitrigla cuculus & Engelse poon \\
\hline Scorpaeniformes & Triglidae & Eutrigla & Eutrigla gurnardus & Grauwe poon \\
\hline Scorpaeniformes & Triglidae & Trigla & Trigla lucerna & Rode poon \\
\hline Scorpaeniformes & Triglidae & Trigloporus & Trigloporus lastoviza & Gestreepte poon \\
\hline Stomiiformes & Sternoptychidae & Maurolicus & Maurolicus muelleri & Lichtend sprotje \\
\hline Syngnathiformes & Centriscidae & Macroramphosus & Macroramphosus scolopax & Snipvis* \\
\hline Syngnathiformes & Syngnathidae & Entelurus & Entelurus aequoreus & Adderzeenaald \\
\hline Syngnathiformes & Syngnathidae & Hippocampus & Hippocampus hippocampus & \\
\hline Syngnathiformes & Syngnathidae & Hippocampus & Hippocampus ramulosus & Zeepaardje \\
\hline & & & & Kleine \\
\hline Syngnathiformes & Syngnathidae & Nerophis & Nerophis lumbriciformis & wormzeenaald* \\
\hline Syngnathiformes & Syngnathidae & Syngnathus & Syngnathus acus & Grote zeenaald \\
\hline Syngnathiformes & Syngnathidae & Syngnathus & Syngnathus rostellatus & Kleine zeenaald \\
\hline Syngnathiformes & Syngnathidae & Syngnathus & Syngnathus typhle & Trompetterzeenaald \\
\hline Tetraodontiformes & Balistidae & Balistes & Balistes carolinensis & Trekkervis \\
\hline Tetraodontiformes & Molidae & Mola & Mola mola & Maanvis \\
\hline Zeiformes & Zeidae & Zeus & Zeus faber & Zonnevis \\
\hline
\end{tabular}

*Indicates introduced species. 
Wageningen Marine Research

T +31 (0)317480900

E: marine-research@wur.nl

www.wur.eu/marine-research

Visitors' address

- Ankerpark 271781 AG Den Helder

- Korringaweg 7, 4401 NT Yerseke

- Haringkade 1, 1976 CP IJmuiden
With knowledge, independent scientific research and advice, Wageningen Marine Research substantially contributes to more sustainable and more careful management, use and protection of natural riches in marine, coastal and freshwater areas. 